\title{
Taxonomy and distribution of Pectinariidae (Annelida) from Iceland with a comparative analysis of uncinal morphology
}

\author{
Julio PARAPAR ${ }^{1, *}$, Verónica PALOMANES ${ }^{2}$, \\ Gudmundur V. HELGASON ${ }^{3}$ \& Juan MOREIRA ${ }^{4}$ \\ ${ }^{1,2}$ Departamento de Bioloxía, Universidade da Coruña, 15008 A Coruña, Spain. \\ ${ }^{3}$ Deceased 9 May 2020. Former addresss: RORUM ehf., Brynjólfsgötu 5, 107 Reykjavík, Iceland. \\ ${ }^{4}$ Departamento de Biología (Zoología), Universidad Autónoma de Madrid, \\ Cantoblanco, 28049 Madrid, Spain. \\ ${ }^{4}$ Centro de Investigación en Biodiversidad y Cambio Global (CIBC-UAM), \\ Universidad Autónoma de Madrid, 28049 Madrid, Spain. \\ *Corresponding author: julio.parapar@udc.es \\ 2Email: veronica.palomanes@udc.es \\ Email: juan.moreira@uam.es \\ ${ }^{1}$ urn:lsid:zoobank.org:author:CE188F30-C9B0-44B1-8098-402D2A2F9BA5 \\ ${ }^{2}$ urn:lsid:zoobank.org:author:6C644341-D35B-42B6-9857-5F119457A424 \\ ${ }^{3}$ urn:1sid:zoobank.org:author:32B3520E-1D49-4B77-BF81-2AAE3FE76363 \\ ${ }^{4}$ urn:lsid:zoobank.org:author:B1E38B9B-7751-46E0-BEFD-7C77F7BBBEF0
}

This paper is dedicated to Guðmundur Vidir Helgason who passed away on 9 May 2020, just before publication of this paper. Project Manager at RORUM, an environmental research and consulting company, he was previously a Project Coordinator for the BIOICE program (Benthic Invertebrates of Icelandic Waters) and Director of the Sandgerði Marine Centre from 1992 to 2013, being one of the organizers of the $7^{\text {th }}$ International Polychaete Conference (Reykjavík, July 2001).

\begin{abstract}
Based on samples collected during the BIOICE project off Iceland, four species of marine annelids belonging to the family Pectinariidae were identified: Amphictene auricoma (O.F. Müller, 1776), Cistenides granulata (Linnaeus, 1767), Cistenides hyperborea Malmgren, 1865 and Lagis koreni Malmgren, 1866. Taxonomic remarks and data on geographical and bathymetric distribution are presented. The distribution of each species off Iceland was evaluated and two patterns were defined: C. granulata and C. hyperborea were mainly found in waters off the northeast coast, while A. auricoma and L. koreni were found on the southern coast. Several body characters with taxonomic value in this family were reviewed under the stereo microscope and scanning electron microscope, with special emphasis on the neuropodial uncini. Remarks on these special chaetae are included in the diagnoses.
\end{abstract}


Keywords. SEM, Polychaeta, distribution, species diversity.

Parapar J., Palomanes V., Helgason G.V. \& Moreira J. 2020. Taxonomy and distribution of Pectinariidae (Annelida) from Iceland with a comparative analysis of uncinal morphology. European Journal of Taxonomy 666: 1-32. https://doi.org/10.5852/ejt.2020.666

\section{Introduction}

The BIOICE (Benthic Invertebrates of Icelandic Waters) expeditions started in 1992 aiming at characterizing the marine benthic fauna living in the 200-mile economic zone of Iceland in a depth range of 20 to $3500 \mathrm{~m}$. Sampling was carried out at both sides of the Greenland-Iceland-Faeroe Ridge (GIF Ridge) that separates water masses with different oceanographic features (Hansen \& Østerhus 2000). In this sense, several water masses associated with submarine ridges are present around Iceland, influencing the flow of several cold and warm water currents (Silva et al. 2017), dividing its coast into three distinct regions (Fig. 1A), and therefore limiting the distribution of the marine species (Brix \& Svavarsson 2010; Meißner et al. 2014; Silva et al. 2017).
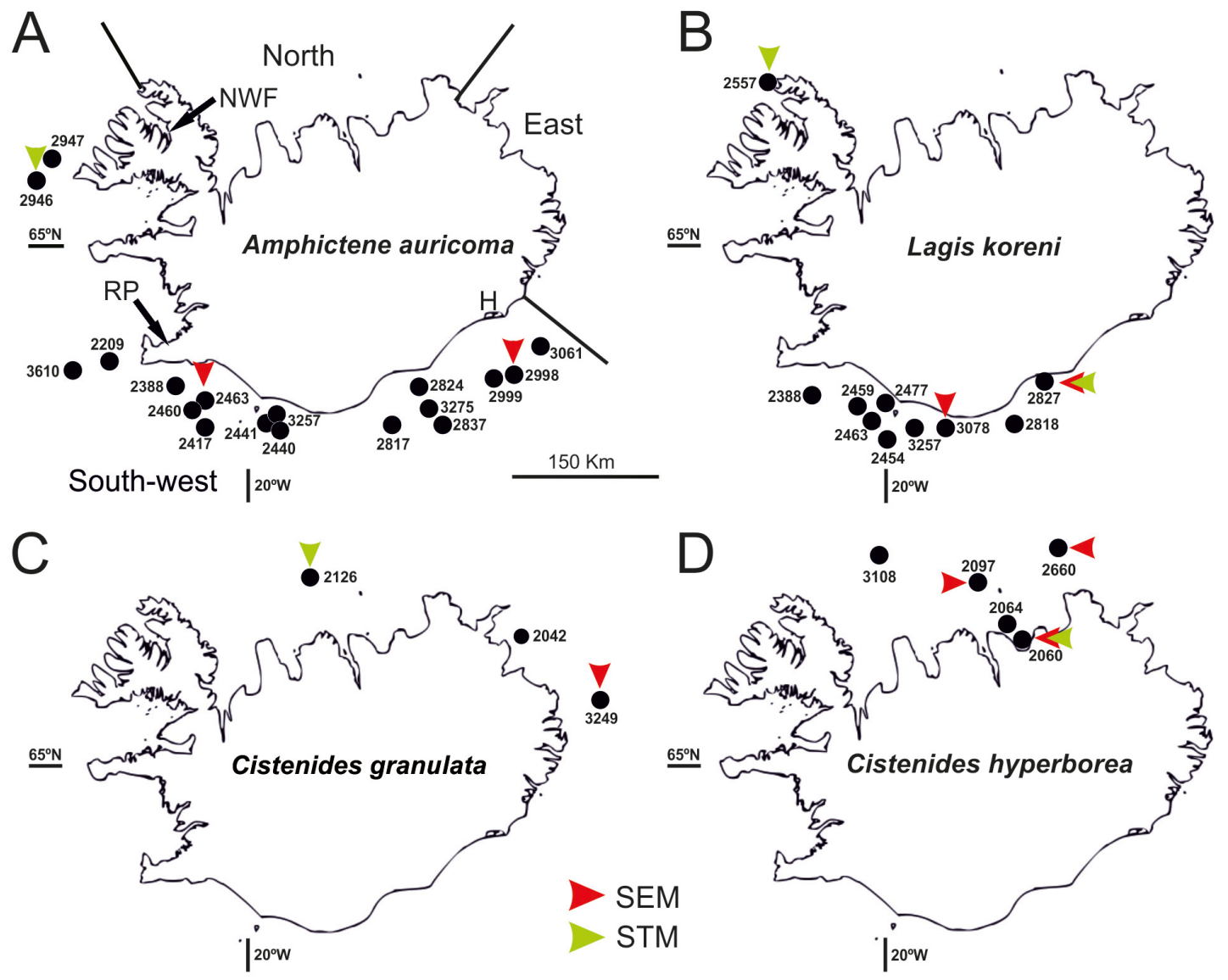

Fig. 1. Maps of Iceland showing distribution of the species of Pectinariidae found in BIOICE samples. A. Amphictene auricoma (O.F. Müller, 1776). B. Lagis koreni Malmgren, 1866. C. Cistenides granulata (Linnaeus, 1767). D. Cistenides hyperborea Malmgren, 1866. The three main coastal sectors around Iceland are shown in A. The specimens photographed and studied under SEM are indicated with green and red arrowheads, respectively. Abbreviations: $\mathrm{H}=\mathrm{Höfn}$; NWF $=$ North-western fjords; $\mathrm{RP}=$ Reykjanes Peninsula. 
The polychaete fauna (Annelida Lamarck, 1809) yielded by the BIOICE expeditions has been extensively studied in the last two decades, for instance by Petersen (2000: Fauveliopsidae Hartman, 1971), Kirkegaard (2001: Glyceridae Grube, 1850 and Goniadidae Kinberg, 1866), Sanfilippo (2001: Serpulidae Rafinesque, 1815), Sigvaldadóttir (2002: Spionidae Grube, 1850), Chambers \& Woodham (2003: Cirratulidae Ryckholt, 1851), Parapar (2003, 2006: Oweniidae Rioja, 1917), Moreira \& Parapar (2012, 2015: Sphaerodoridae Malmgren, 1867), Parapar et al. (2011a, 2011b, 2011c, 2013a, 2013b, 2014a, 2014b: Trichobranchidae Malmgren, 1866, Opheliidae Malmgren, 1867, Ampharetidae Malmgren, 1866 and Longosomatidae Hartman, 1944) and Zamora et al. (2020: Fauveliopsidae). However, other families well represented in such samples have not been studied yet such as the Pectinariidae Quatrefages, 1866.

The family Pectinariidae was traditionally composed of five genera (Malmgren 1866): Pectinaria Savigny in Lamarck, 1818, Amphictene Lamarck, 1818, Cistenides Malmgren, 1866, Lagis Malmgren, 1866 and Petta Malmgren, 1866; this classification was followed, for instance, by Long (1973), Fauchald (1977) and Wolf (1984). However, other authors only recognized Pectinaria and Petta, considering the other three as subgenera of Pectinaria (e.g., Hessle 1917; Fauvel 1927; Hartman 1941; Day 1967; Holthe 1986). We follow Hutchings \& Peart (2002), who recognized the five aforementioned genera and provided a diagnosis for each genus, together with a table listing the major diagnostic characters; this systematic arrangement was also followed by recent workers such as Garraffoni \& Camargo (2006), Nogueira et al. (2019) and Read \& Fauchald (2019).

All five pectinariid genera occur in European waters, and are represented by seven species and one subspecies (Gil 2011). Among these, Amphictene auricoma mediterranea Nilsson, 1928 and Lagis neapolitana (Claparède, 1869) have only been reported from the Mediterranean Sea. The remaining six species, namely Amphictene auricoma (O.F. Müller, 1776), Cistenides granulata (Linnaeus, 1767), C. hyperborea Malmgren, 1865, Lagis koreni Malmgren, 1866, Pectinaria belgica (Pallas, 1766) and Petta pusilla Malmgren, 1866, are distributed across the NE Atlantic coasts; A. auricoma, C. granulata, C. hyperborea and L. koreni have been also recorded in Iceland prior to the present study (WesenbergLund 1951).

Among other characters, the terebelliform polychaetes, and the Pectinariidae in particular, are characterized by having neurochaetae modified as uncini for anchoring the body within the tube, in order to avoid the risk of predation (Hutchings 2000; Rouse \& Pleijel 2001; Garraffoni \& Camargo 2006). Nogueira et al. (2019) (based on Rouse \& Pleijel 2001; Hutchings \& Peart 2002; Nogueira et al. 2010; Zhang \& Qiu 2017) refer to two types of neurochaetal uncini in Pectinariidae: A) Pectinate uncini, with an anterior peg (hereafter 'subrostral process') composed of densely packed denticles, uncinal teeth (hereafter 'main teeth') long and thin, arranged in longitudinal rows, and main fang (hereafter 'rostrum') absent; and B) Avicular uncini, with rostrum present and secondary teeth in transverse rows and progressively shorter distally (hereafter 'capitium').

In this paper, we study the diversity and distribution of the Pectinariidae around Iceland after a number of samples collected during the BIOICE cruises. The aforementioned species are reported here again for Iceland and remarks about their taxonomy and ecology are provided. Furthermore, we have also studied the uncini in specimens of different body sizes for all four species; this was done by using the SEM in order to test 1) whether there were morphological differences supposedly related to ontogeny and 2) whether this uncini variability showed any pattern both within a species and among species and therefore could be used as a taxonomic character.

\section{Material and methods}

This study is based on material collected in the framework of the BIOICE project. A total of 1066 pectinariid specimens were found in 43 samples; some specimens in eight samples could not be identified because of their small size or bad preservation (e.g., fragmented body). Samples were initially fixed in $10 \%$ formalin buffered with borax, and then preserved in $70 \%$ ethanol. Specimens were picked from 
samples by the staff of the Sandgerdi Marine Centre (SMC, Iceland). Most of the material examined was deposited in the collections of the Icelandic Institute of Natural History (IINH, Reykjavík); several selected specimens were deposited in the Museo Nacional de Ciencias Naturales (MNCN, Madrid).

Abiotic data of all BIOICE samples are available from the following link: http://utgafa.ni.is/greinar/BIOICE_station_list_91-04_Paper_A2.pdf

Identification of specimens and stereomicrographs were done using an Olympus SZX9 stereo microscope at the Facultade de Ciencias, Universidade da Coruña (UDC, Spain). Specimens used for examination with SEM were prepared by critical point drying, covered with gold in a BAL-TEC SCD 004 evaporator and examined and photographed under a JEOL JSM-6400 scanning electron microscope (SEM) at the Servizos de Apoio á Investigación (SAI-UDC, Spain).

Nomenclature for morphological characters, genera, species and synonyms mostly follows Holthe (1986) and Hutchings \& Peart (2002). Each species is related to water mass(es) as described by Brix \& Svavarsson (2010) according to geographic location (coordinates), depth and temperature.

\section{List of morphological abbreviations}

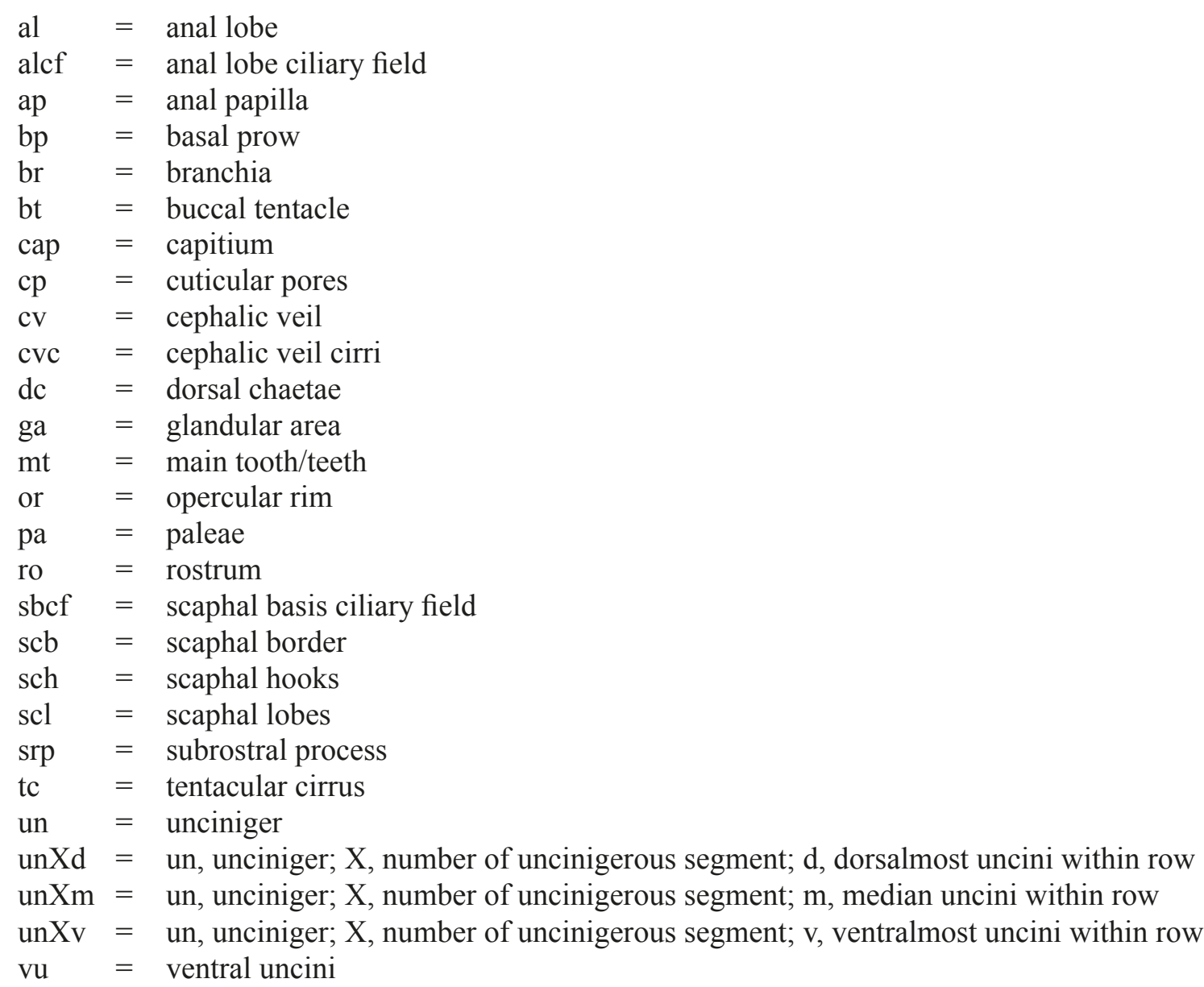

\section{List of water mass abbreviations}

$\mathrm{CW}=$ Coastal Waters

MEIW $=$ Modified East Icelandic Water

MNAW $=$ Modified North Atlantic Waters

NSAIW $=$ Norwegian Sea Arctic Intermediate Waters 


\section{Results}

\section{Taxonomy}

The study of the samples collected during the BIOICE project yielded four pectinariid species belonging to three genera. The most abundant species was Lagis koreni (801 specs; $75.1 \%$ of the total pectinariid specimens identified), followed by Amphictene auricoma (117 specs; 11.0\%), Cistenides hyperborea (125 specs; $11.7 \%$ ) and $C$. granulata (23 specs; 2.2\%). All four species show a well-defined geographical distribution around Iceland corresponding to narrow ranges of temperature and depth, but being mostly present in temperate waters at depths of between 100 and $300 \mathrm{~m}$ (Figs 1-2); there were some exceptions to this pattern corresponding to samples with C. hyperborea and L. koreni. Abundance and distribution around Iceland of each species and taxonomic remarks are presented and discussed below.

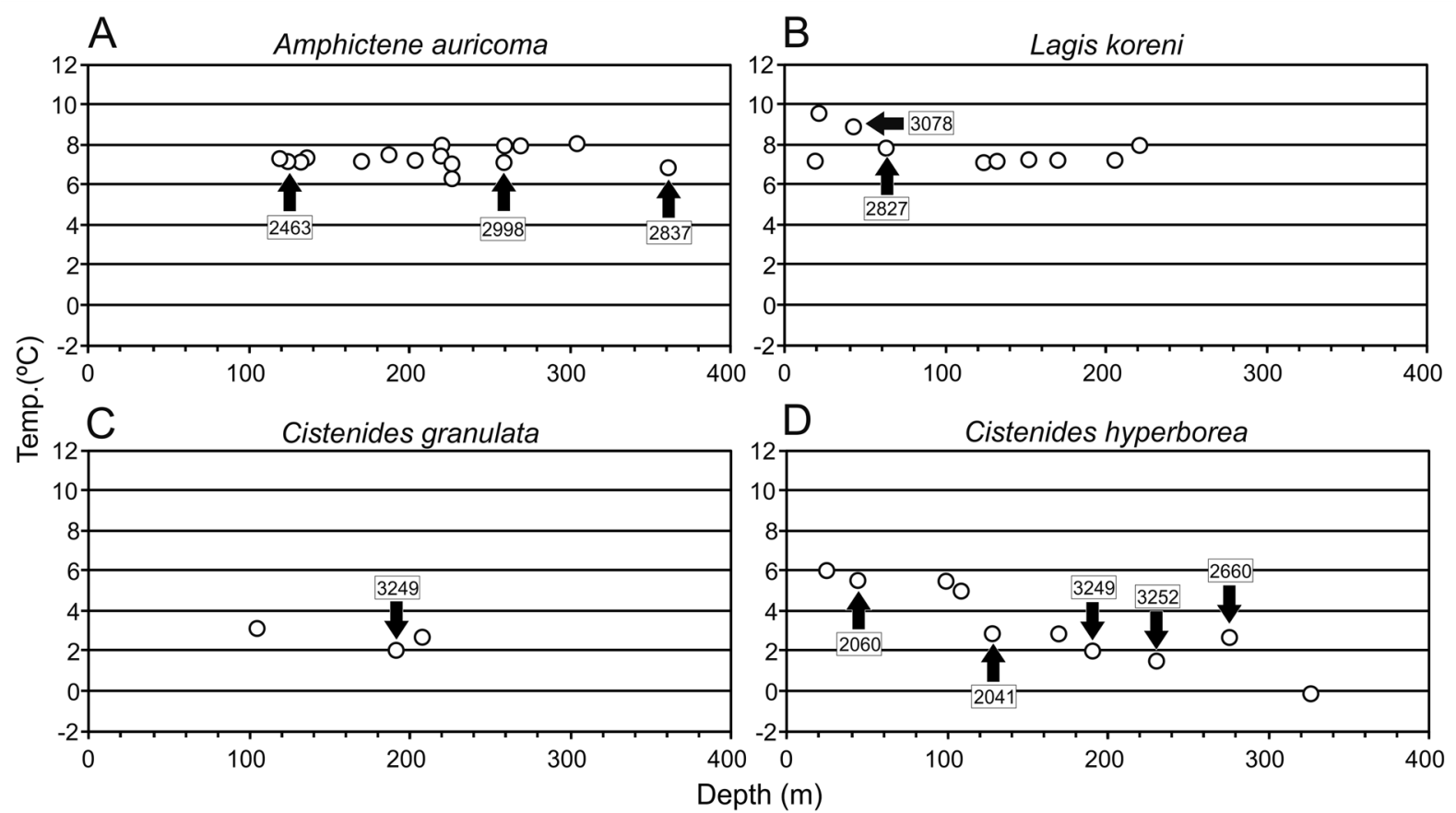

Fig. 2. Temperature vs depth data of the BIOICE samples where specimens of Pectinariidae were found. A. Amphictene auricoma (O.F. Müller, 1776). B. Lagis koreni Malmgren, 1866. C. Cistenides granulata (Linnaeus, 1767). D. Cistenides hyperborea Malmgren, 1866. Specimens studied under SEM are indicated with black arrows and sample numbers.

Phylum Annelida Lamarck, 1809

Family Pectinariidae Quatrefages, 1866

Genus Amphictene Lamarck, 1818

\section{Type species and type locality}

Amphictene auricoma Müller, 1776. Denmark; type probably lost or never designated (Holthe 1986).

\section{Remarks}

The genus is characterized according to Hutchings \& Peart (2002) by having neurochaetal uncini with major teeth arranged in two rows. However, an examination of BIOICE specimens of A. auricoma suggests that this character could be reassessed (see Discussion below). 
Amphictene auricoma (O.F. Müller, 1776)

Figs 1A, 2A, 3A, 4A-B, 5-7

Amphitrite auricoma O.F. Müller, 1776: 216.

Amphictene auricoma - Malmgren 1865: 357. — Hutchings \& Peart 2002: 103, table 1.

Pectinaria auricoma - Hessle 1917: 78. — Jirkov \& Leontovich 2013: 220, key.

Pectinaria (Amphictene) auricoma - Fauvel 1927: 222. — Holthe 1986: 22. — Hartmann-Schröder 1996: 480. - Kirkegaard 1996: 280.

Material examined (117 specimens, $11.0 \%$ of all specimens identified, in 18 samples)

ICELAND - North Western Fjords • 3 specs; BIOICE station 489, sample 2946; 6547'90" N, $25^{\circ} 38^{\prime} 70^{\prime \prime} \mathrm{W} ; 28$ Aug. 1996; $6.20^{\circ} \mathrm{C}$; 35.05 ppm; $228 \mathrm{~m}$ depth; sandy silt; IINH-40181 1 spec.; BIOICE

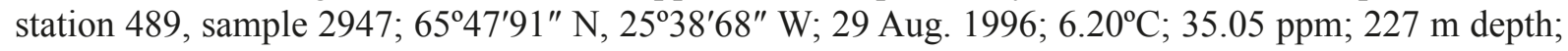
sediment unknown; IINH-40211. - South West to South East coast - 1 spec.; BIOICE station 968,

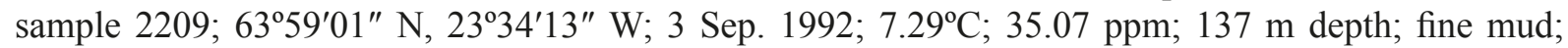

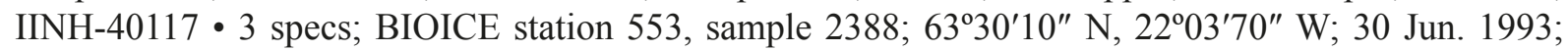
$7.13^{\circ} \mathrm{C}$; $35.10 \mathrm{ppm} ; 171 \mathrm{~m}$ depth; silty sand; IINH-27841 1 spec.; BIOICE station 564, sample 2417; $63^{\circ} 09^{\prime} 90^{\prime \prime} \mathrm{N}, 21^{\circ} 11^{\prime} 80^{\prime \prime} \mathrm{W}$; 2 Jul. $1993 ; 7.08^{\circ} \mathrm{C}$; $35.11 \mathrm{ppm} ; 259 \mathrm{~m}$ depth; sandy silt; IINH-40113 •

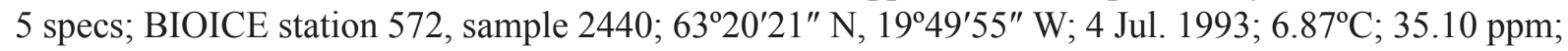
228 m depth; sandy silt; MNCN 16.01/17982 - 1 spec.; BIOICE station 572, sample 2441; 6320'17" N,

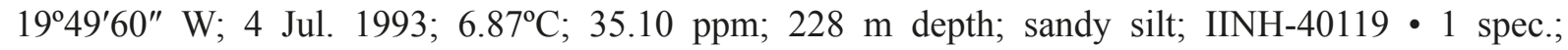
BIOICE station 582, sample 2460; 63⒉ $9^{\prime} 65^{\prime \prime} \mathrm{N}, 21^{\circ} 39^{\prime} 10^{\prime \prime} \mathrm{W} ; 5$ Jul. 1993; $7.10^{\circ} \mathrm{C} ; 35.08$ ppm; $125 \mathrm{~m}$ depth; sediment unknown; IINH-40127 • 42 specs; BIOICE station 583, sample 2463; 63⒉ $25^{\prime} 40^{\prime \prime} \mathrm{N}$, $21^{\circ} 39^{\prime} 89^{\prime \prime} \mathrm{W} ; 5$ Jul. $1993 ; 7.12^{\circ} \mathrm{C} ; 35.08$ ppm; $133 \mathrm{~m}$ depth; silty sand and gravel; IINH-40155 • 4 specs;
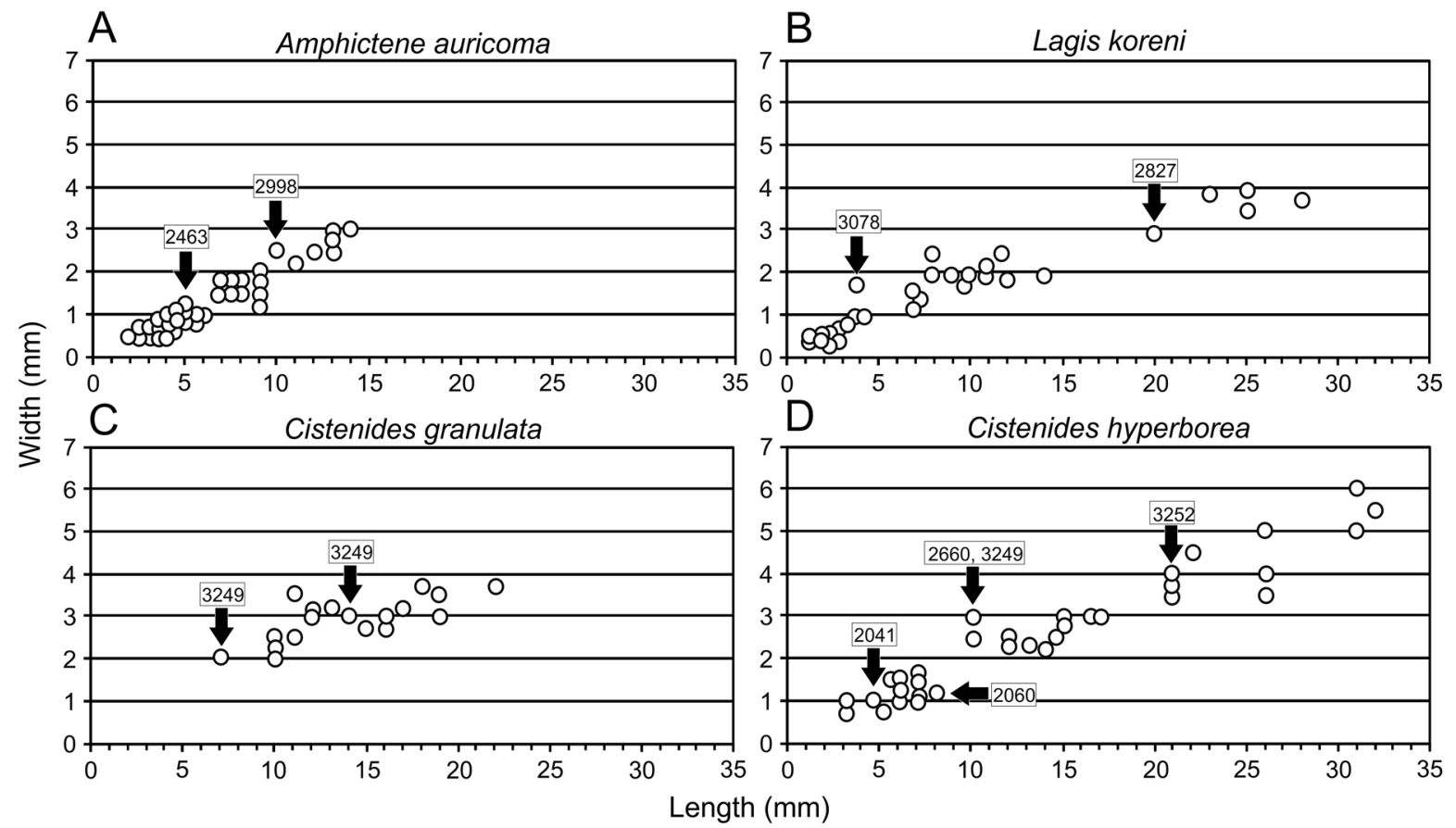

Fig. 3. Biometric features of the Pectinariidae specimens in BIOICE samples. A. Amphictene auricoma (O.F. Müller, 1776). B. Lagis koreni Malmgren, 1866. C. Cistenides granulata (Linnaeus, 1767). D. Cistenides hyperborea Malmgren, 1866. Specimens studied under SEM are indicated with black arrows and sample numbers. 
PARAPAR J. et al., Taxonomy and distribution of Pectinariidae (Annelida) from Iceland

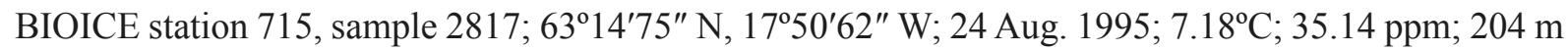

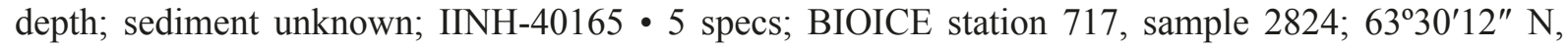
$17^{\circ} 42^{\prime} 07^{\prime \prime} \mathrm{W} ; 25$ Aug. 1995; 7.24 ${ }^{\circ} \mathrm{C} ; 35.13$ ppm; $120 \mathrm{~m}$ depth; gravelly sand; IINH-40166 • 6 specs;

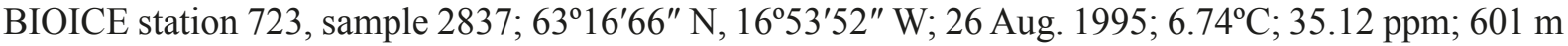

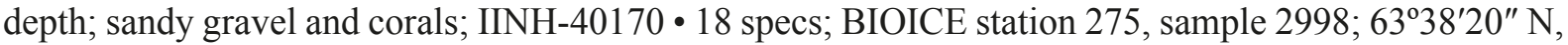

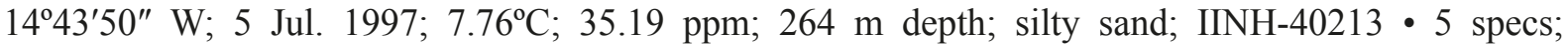

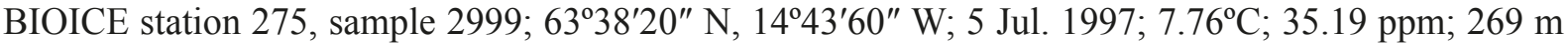
depth; sediment unknown; IINH-40293 - 14 specs; BIOICE station 299, sample 3061; 63⒌'49" N, $14^{\circ} 09^{\prime} 21^{\prime \prime} \mathrm{W} ; 10$ Jul. 1997; 7.59 ${ }^{\circ} \mathrm{C} ; 35.16$ ppm; $221 \mathrm{~m}$ depth; sediment unknown; IINH-40461 4 specs;

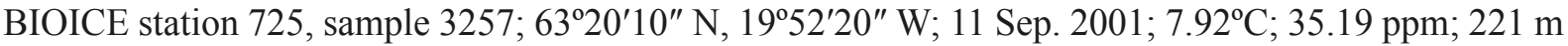
depth; sediment unknown; IINH-40462 - 1 spec.; BIOICE station 734, sample 3275; 63⒉ $23^{\prime} 10^{\prime \prime} \mathrm{N}$, $16^{\circ} 16^{\prime} 20^{\prime \prime} \mathrm{W} ; 15$ Sep. $2001 ; 7.97^{\circ} \mathrm{C} ; 35.20$ ppm; $305 \mathrm{~m}$ depth; sediment unknown; IINH-40463 • $1 \mathrm{spec}$.;

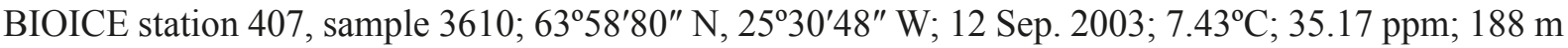
depth; silty sand; IINH-40464.

\section{Occurrence}

From off West and South of Reykjanes Peninsula to Höfn at SE; two additional samples from off northwestern fjords (Fig. 1). Depth range: 120 to $305 \mathrm{~m}$ (sample 2837: $601 \mathrm{~m}$, not shown); bottom temperature range: 6.20 to $7.97^{\circ} \mathrm{C}$ (Fig. 2A). Water mass/es: MNAW.
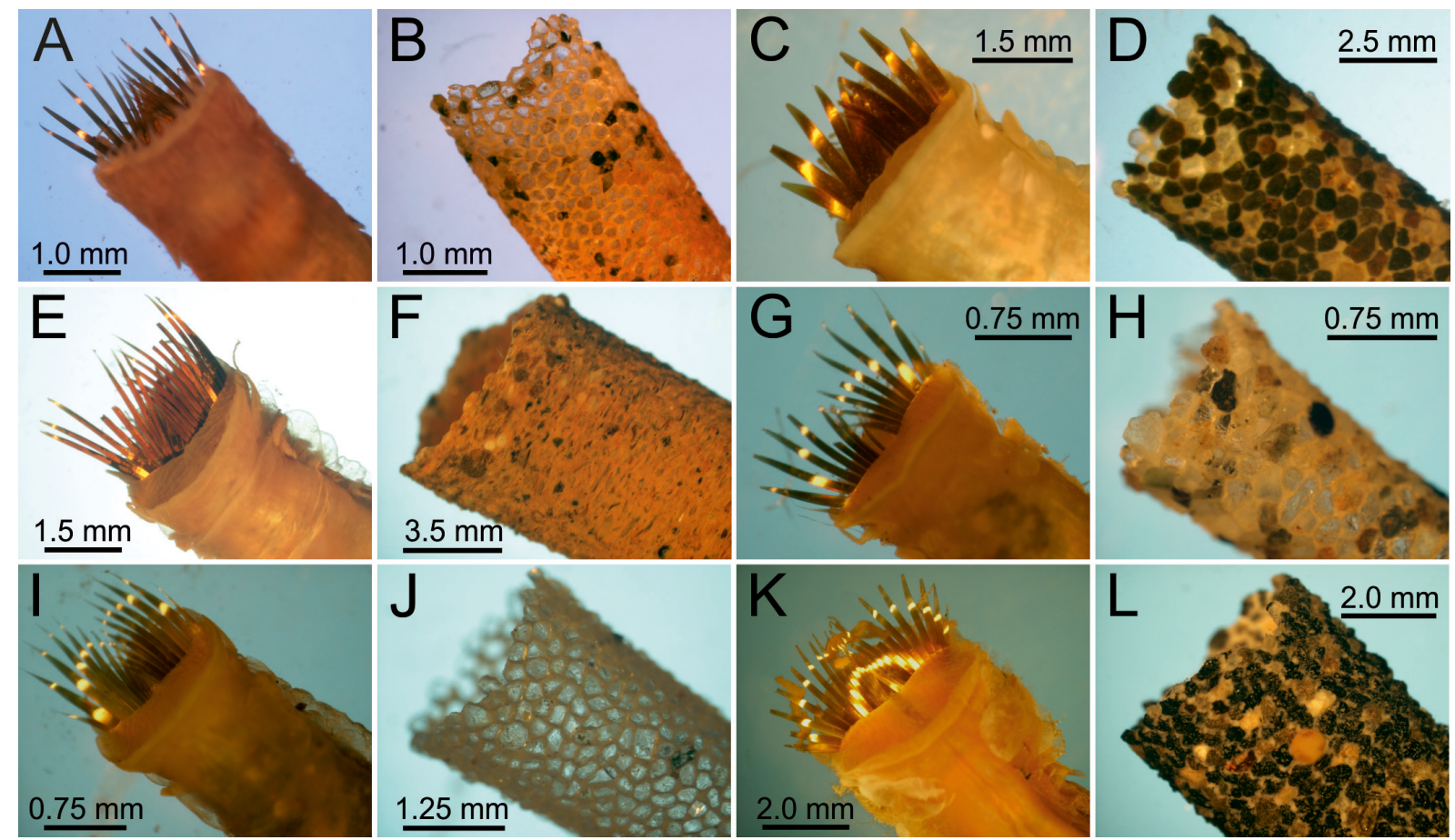

Fig. 4. Stereomicrographs of anterior body ends (dorsal view) and anterior end of the tube. A-B. Amphictene auricoma (O.F. Müller, 1776) (BIOICE sample 2946, IINH-40181). C-D. Cistenides granulata (Linnaeus, 1767) (sample 2126, IINH-40466). E-H. Cistenides hyperborea Malmgren, 1866 (E-F: sample 3252, IINH-40477; G-H: sample 2060, IINH-40471). I-L. Lagis koreni Malmgren, 1866 (I-J: sample 2557; K-L: sample 2827, IINH-40485). 

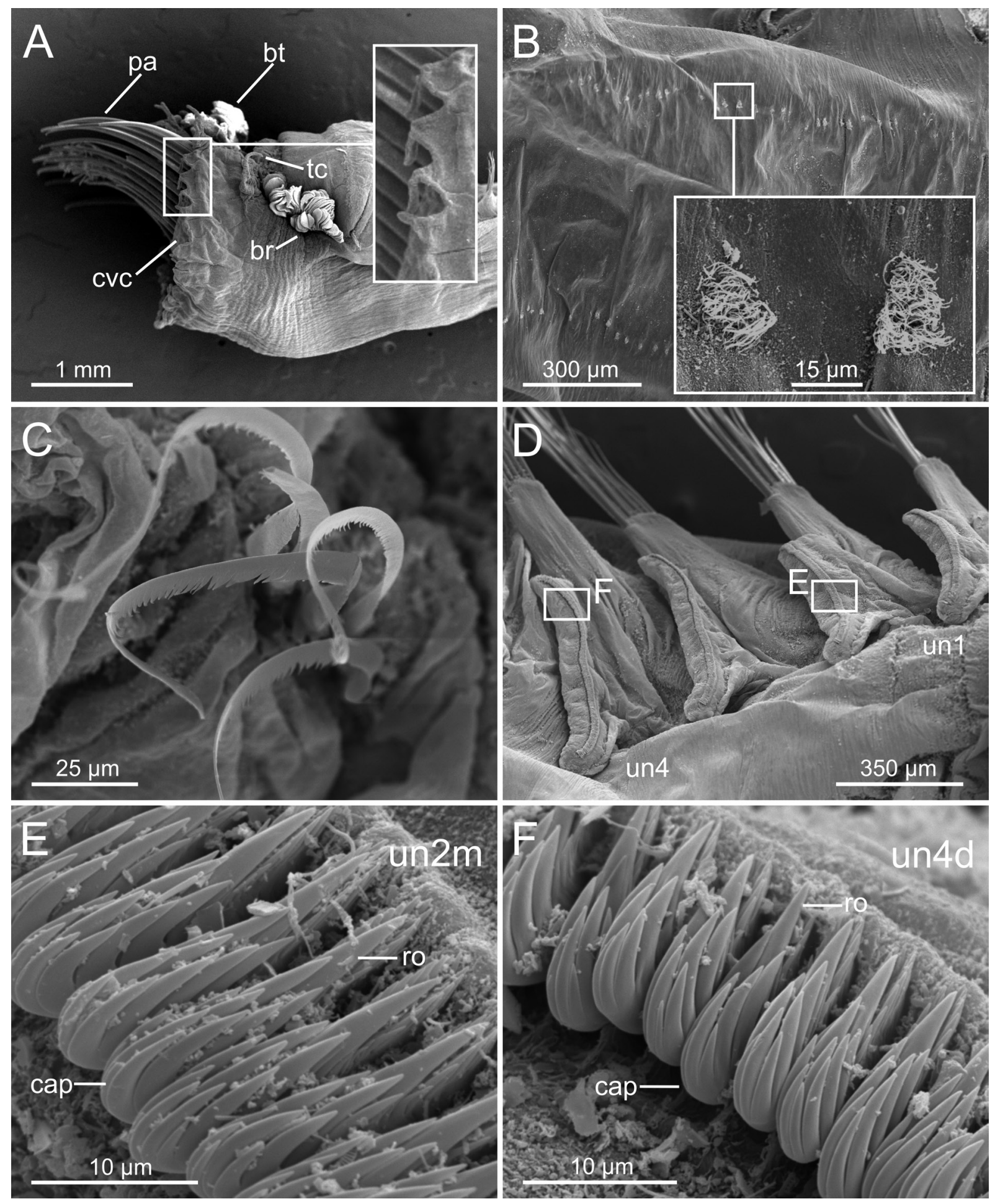

Fig. 5. Amphictene auricoma (O.F. Müller, 1776). SEM micrographs from two large specimens (BIOICE sample 2998, IINH-40213). A. Anterior end, left lateral view (framed: cirri of opercular rim, detail). B. Ventral rows of ciliated tufts (framed: two tufts, detail). C. Notochaetae; distal end. D. Uncinigers 1 to 4. E. Unciniger 2, median uncini (framed in D). F. Unciniger 4, dorsal uncini (framed in D). 
PARAPAR J. et al., Taxonomy and distribution of Pectinariidae (Annelida) from Iceland
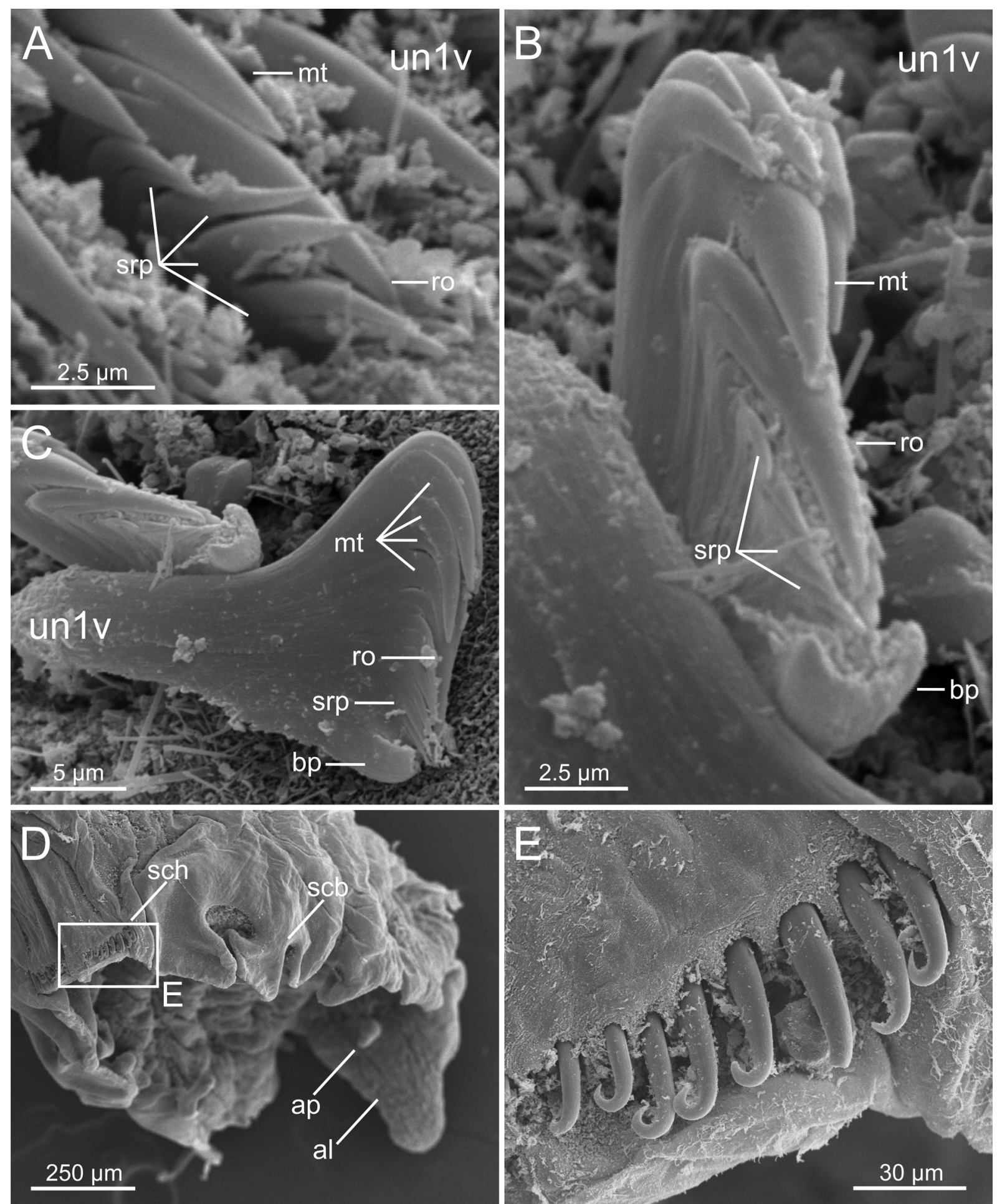

Fig. 6. Amphictene auricoma (O.F. Müller, 1776). SEM micrographs from a large specimen (BIOICE sample 2998, IINH-40213). A-C. Unciniger 1, ventral uncinus, frontolateral, frontal and lateral views, respectively. D. Scaphe. E. Scaphal hooks (framed in D). 


\section{Remarks}

Species of Amphictene bear a characteristic crenulated opercular rim, that is not present in other genera (Figs 4A, 5A). Amphictene auricoma - type locality: Denmark (Holthe 1986) - has been the only species of the genus reported in North Atlantic waters and also bears thick paleae with sharp tips (Fig. 5A), scaphe with crenulated margins (Fig. 6D), 17 uniramous and 13 biramous chaetigers, and distally curved scaphal hooks (Fig. 6E). However, Hutchings \& Peart (2002: table 1) pointed out that there is "a considerable variation recorded for this species" in the North Atlantic. General morphology of BIOICE specimens agree well with previous descriptions and the aforementioned characters; however, SEM examination revealed that several pygidial and uncini features differ from what was described for A. auricoma. First, Holthe (1986: fig. 4c) and Hartmann-Schröder (1996: fig. 234c) mentioned a long "anal tongue" and "anal cirrus", corresponding to the "anal lobe" and "anal papilla" (after Hutchings \& Peart 2002), that are much shorter in BIOICE specimens (Fig. 6D).

On the other hand, the uncini of $A$. auricoma have been described as having 1-2 vertical rows of main teeth (cf. Hartmann-Schröder 1971: fig. 157b, and later works: Holthe 1986: fig. 4e; Hartman-Schröder 1996: fig. 234b). However, SEM micrographs of BIOICE material shows a well-defined rostrum, surrounded in all its length by long teeth forming, in turn, a subrostral process (Fig. 6A-B); the rostrum is surmounted by a capitium constituted by many large teeth not arranged in vertical lines (as described in the original description) but with a typical avicular arrangement (Figs 5E-F, 6A-B). Anyway, these uncini may resemble in lateral view (Fig. 6C) the typical ones of A. auricoma and this may have led previous authors to confusion.

In addition, uncinal denticulation shows dorsoventral variation within chaetigers depending on body size. Thus, in large specimens (Fig. 3A) uncini seem avicular along the whole torus (Fig. 5E-F); in smaller ones, the avicular uncini are only found in the dorsal part of the torus (Fig. 7A, C) while in the ventral side all capitium teeth are similar in size and covering most of the rostrum (only showing the pointed distal end; Fig. 7B, D). This pattern is even more evident in the last unciniger, where the capitium teeth seem mixed with those of the subrostral process and leaving a small opening through which the tip of the rostrum is visible (Fig. 7E).

Finally, we have found two longitudinal rows of ciliated tufts/patches along the whole ventral body surface (Fig. 5B) that have not been mentioned in the literature to the best of our knowledge, and those tufts may be related to water irrigation within the tube.

Genus Cistenides Malmgren, 1865

\section{Type species and type locality}

Sabella granulata Linnaeus, 1767. Northern Europe; type never designated (Holthe 1986).

\section{Remarks}

The diagnosis of the genus in Hutchings \& Peart (2002) includes “ ... chaetigers 4 to 16 biramous with notopodia, neuropodia, notochaetae and neurochaetae, chaetiger 17 with notopodia and notochaetae only $(17 / 13)$..." and the presence of a single row of teeth on the uncini as well. Considering the last character, Hutchings \& Peart (2002) transferred four species previously referred to Cistenides, namely C. aegyptia Savigny, 1822, C. chilensis (Nilsson, 1928), C. gouldii Verrill, 1874 and C. regalis Verrill, 1900, to the genus Pectinaria, because of having uncini with two rows of teeth, a character supposedly typical of this genus. We think that both characters could be reconsidered (see Discussion below). 
PARAPAR J. et al., Taxonomy and distribution of Pectinariidae (Annelida) from Iceland

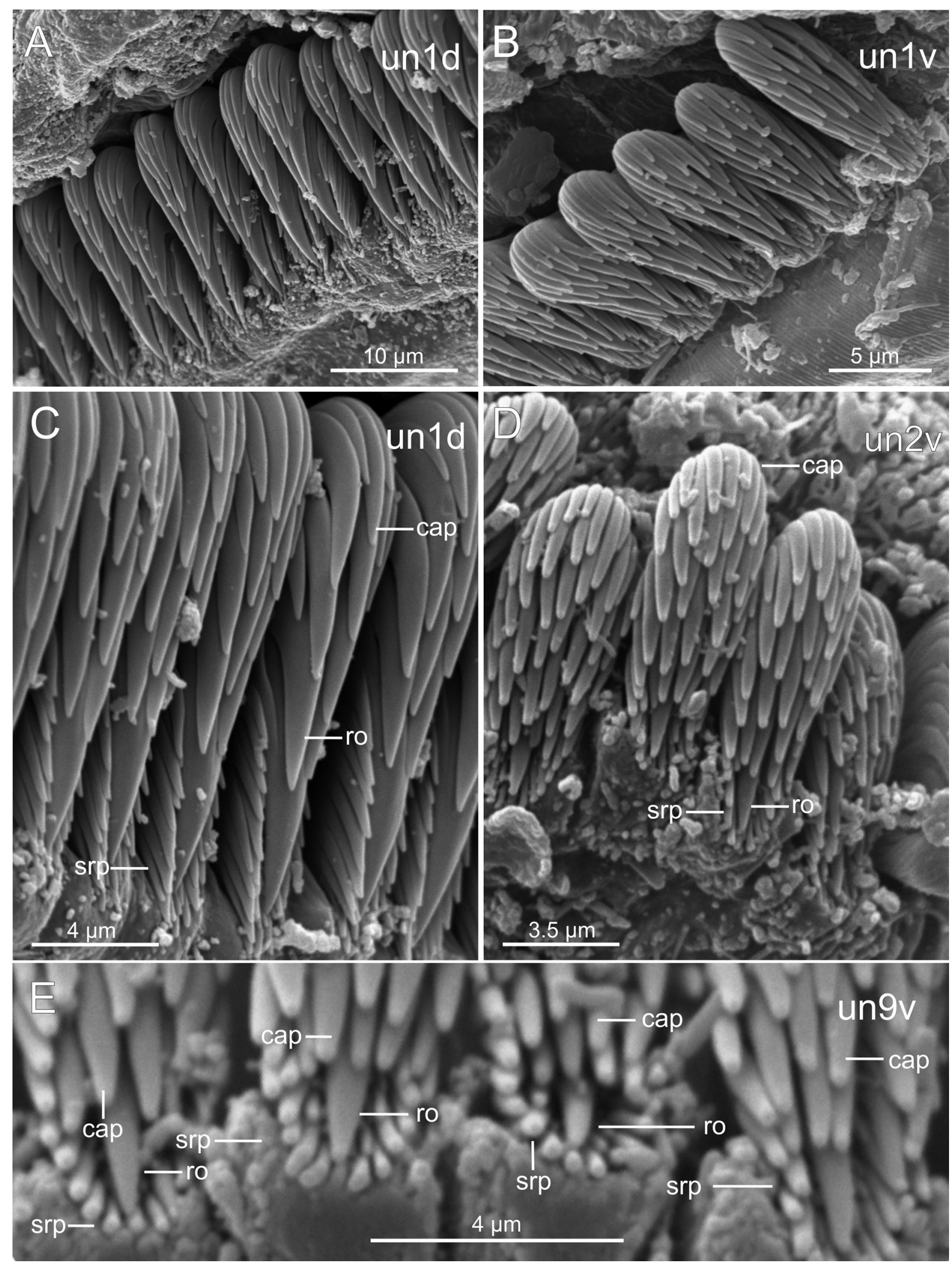

Fig. 7. Amphictene auricoma (O.F. Müller, 1776). SEM micrographs from a small specimen (BIOICE sample 2463, IINH-40481). A-B. Unciniger 1, dorsal and ventral uncini, respectively. C-D. The same in closer view. E. Unciniger 9, ventral uncini, fronto-inferior area. 
Cistenides granulata (Linnaeus, 1767)

Figs $1 \mathrm{C}, 2 \mathrm{C}, 3 \mathrm{C}, 4 \mathrm{C}-\mathrm{D}, 8-9$

Sabella granulata Linnaeus, 1767: 1268.

Pectinaria granulata - Hessle 1917: 77.

Pectinaria (Cistenides) granulata - Nilsson 1928: 28. — Pettibone 1954: 312, fig. 35i-k. - Holthe 1986: 24. — Hartmann-Schröder 1996: 482.

Material examined (23 specimens, $2.2 \%$ of total specimens identified, in three samples)

ICELAND - North and North East coast - 7 specs; BIOICE station 30, sample 2042; 65 49'56" N, $14^{\circ} 32^{\prime} 94^{\prime \prime} \mathrm{W}$; 24 Jul. $1991 ; 3.1^{\circ} \mathrm{C}$; salinity unknown; $105 \mathrm{~m}$ depth; sediment unknown; MNCN 16.01/17988 • 9 specs; BIOICE station 27, sample 2126; 66 $59^{\prime} 51^{\prime \prime} \mathrm{N}, 18^{\circ} 49^{\prime} 82^{\prime \prime} \mathrm{W} ; 8$ Jul. 1992; $2.7^{\circ} \mathrm{C}$; 34.86 ppm; 208 m depth; sandy gravel and stones; IINH-40466 7 specs; BIOICE station 23, sample $3249 ; 65^{\circ} 50^{\prime} 34^{\prime \prime} \mathrm{N}, 12^{\circ} 01^{\prime} 27^{\prime \prime} \mathrm{W} ; 14$ Jul. 2001; $1.92^{\circ} \mathrm{C} ; 34.87$ ppm; $192 \mathrm{~m}$ depth; sediment unknown; IINH-40467.

\section{Occurrence}

From off northern and north-eastern coast of Iceland. Depth range: 105 to $208 \mathrm{~m}$ (Fig. 1C); bottom temperature range: 1.92 to $3.10^{\circ} \mathrm{C}$ (Fig. 2C). Water mass/es: MEIW.

\section{Remarks}

All diagnostic characters for this species - type locality: Northern Europe (Holthe 1986) - as stated by Holthe (1986) are present in BIOICE material: shape and number of paleae and cephalic veil (Figs 4C, 8A, 9A), scaphal shape, anal lobe and anal papilla (Fig. 8F). Ventral uncini agree well with those present in the genus, not showing variations within uncinigers nor along the body both in large (Fig. 8B-E) and small (Fig. 9B-F) specimens; there is only one row of teeth becoming progressively smaller in size from the uncinus base (at the level of the subrostral process) towards the distal end. This lack of variation, which has been considered the typical pattern in the family, was only found in C. granulata among the four pectinariid species in BIOICE samples.

Cistenides hyperborea Malmgren, 1865

Figs 1D, 2D, 3D, 4E-H, 10-15

Cistenides hyperborea Malmgren, 1865: 360.

Pectinaria hyperborea - Hessle 1917: 76.

Pectinaria (Cistenides) hyperborea - Nilsson 1928: 31. — Pettibone 1954: 312, fig. 35c-h. — Holthe 1986: 25. — Hartmann-Schröder 1996: 482.

Material examined (125 specimens, $11.7 \%$ of total specimens identified, in ten samples)

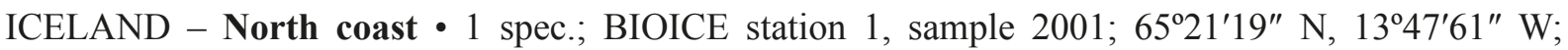
19 Jul. $1991 ; 6.0^{\circ} \mathrm{C}$; salinity unknown; $26 \mathrm{~m}$ depth; organic silt; IINH-40468 - 3 specs; BIOICE

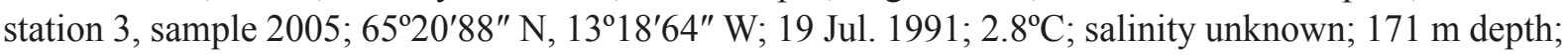
sandy silt and stones; MNCN 16.01/18015 - 1 spec.; BIOICE station 29, sample 2041; 65 48 $61^{\prime \prime} \mathrm{N}$, 14³4'01" W; 24 Jul. 1991; $2.8^{\circ} \mathrm{C}$; salinity unknown; 129 m depth; sediment unknown; IINH-40470 •

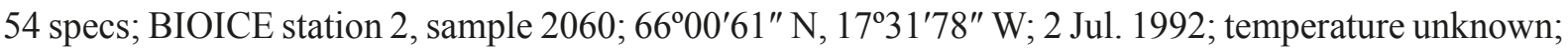
salinity unknown; $48 \mathrm{~m}$ depth; soft sediment; IINH-40471 • 3 specs; BIOICE station 3, sample 2064;

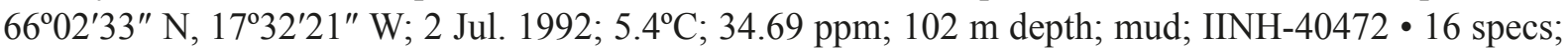


PARAPAR J. et al., Taxonomy and distribution of Pectinariidae (Annelida) from Iceland
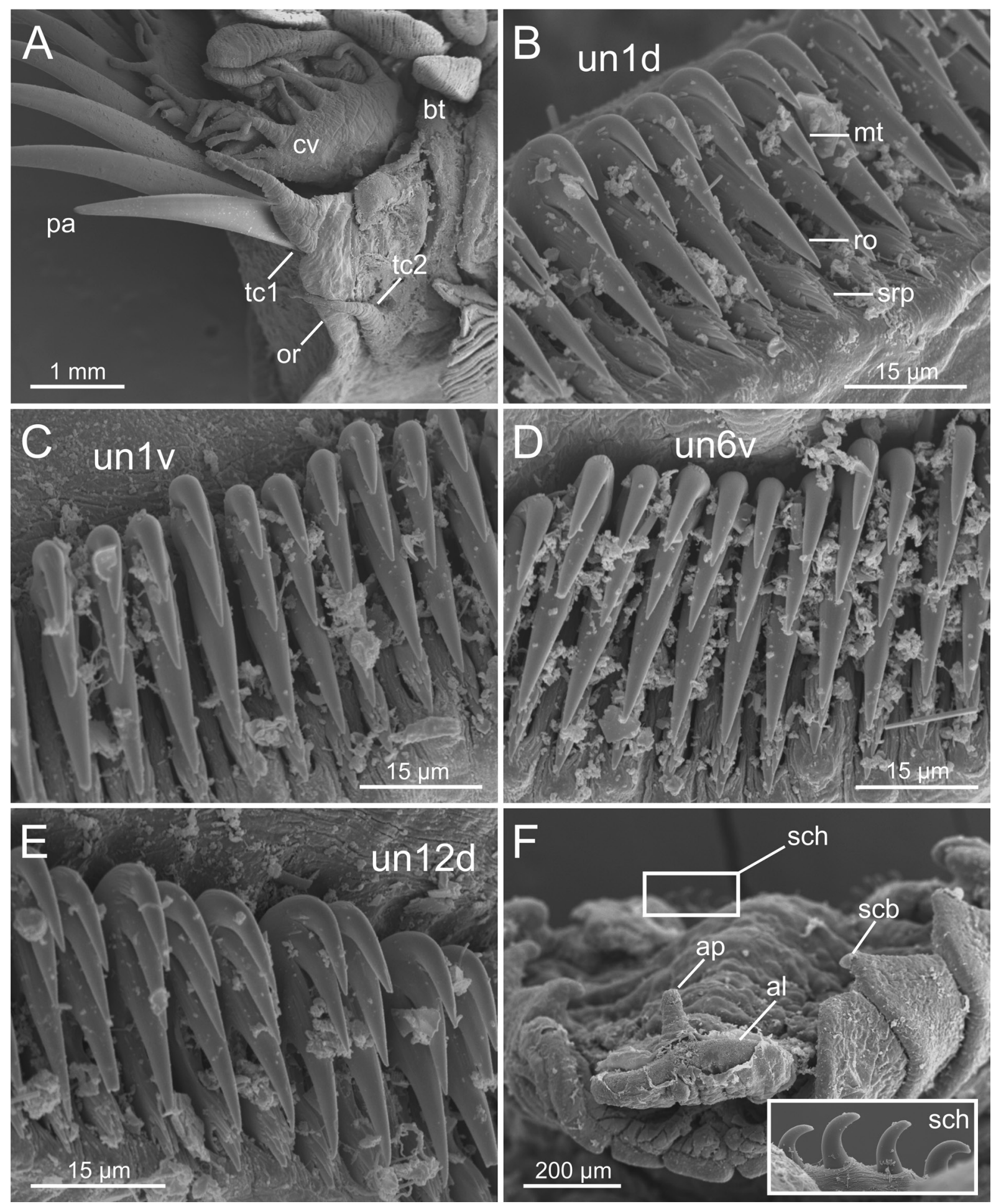

Fig. 8. Cistenides granulata (Linnaeus, 1767). SEM micrographs from two large specimens (BIOICE sample 3249, IINH-40467). A. Anterior end, right lateral view. B-C. Unciniger 1, dorsal and ventral uncini, respectively. D. Unciniger 6, ventral uncini. E. Unciniger 12, dorsal uncini. F. Scaphe, posterodorsal view (framed: scaphal hooks, detail). 


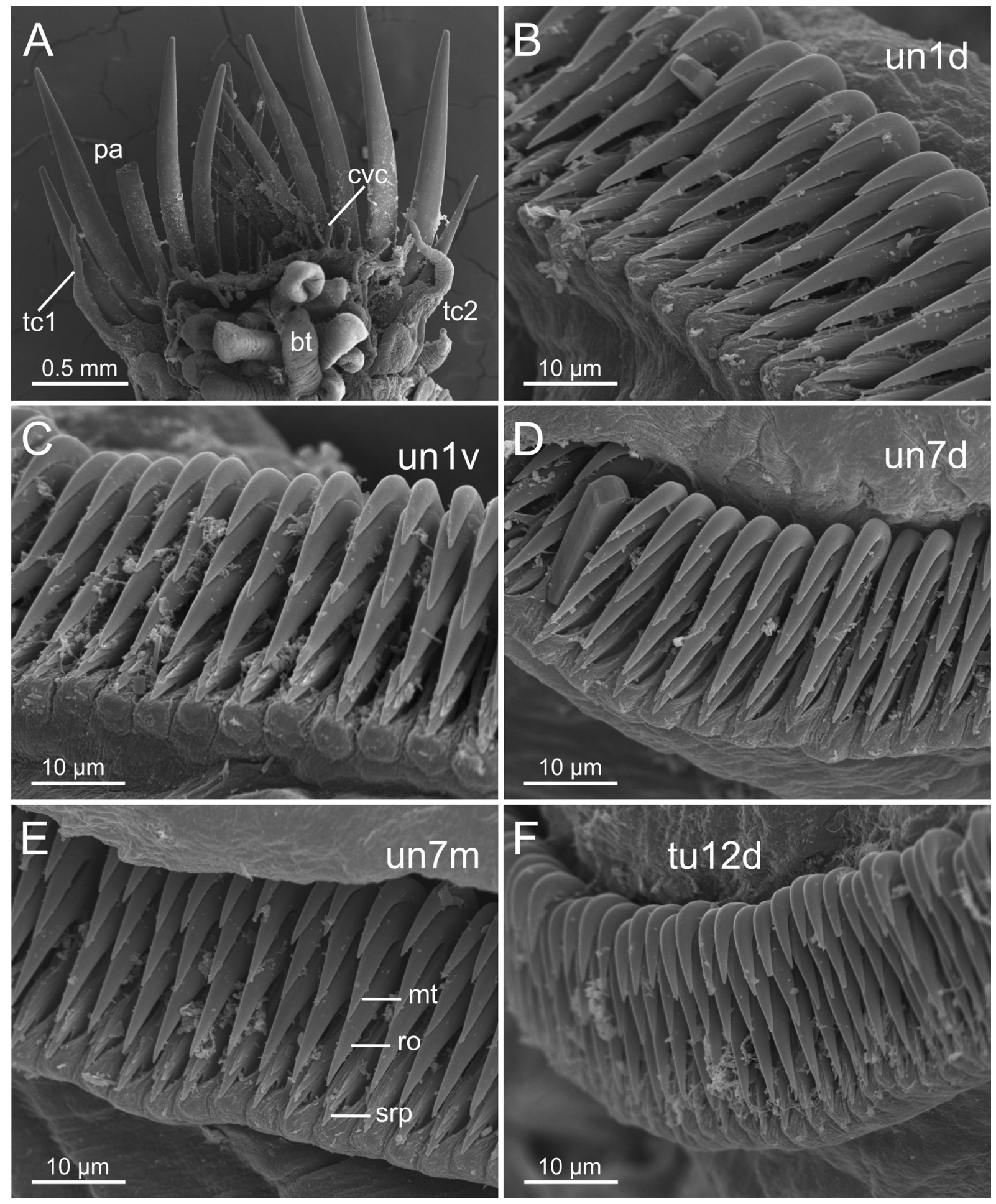

Fig. 9. Cistenides granulata (Linnaeus, 1767). SEM micrographs from a small specimen (BIOICE sample 3249, IINH-40467). A. Anterior end, ventral view. B-C. Unciniger 1, dorsal and ventral uncini, respectively. D-E. Unciniger 7, dorsal and median uncini, respectively. F. Unciniger 12, dorsal uncini. 
BIOICE station 16, sample 2097; 66 $36^{\prime} 92^{\prime \prime} \mathrm{N}, 1^{\circ} 14^{\prime} 42^{\prime \prime} \mathrm{W} ; 5$ Jul. 1992; $4.88^{\circ} \mathrm{C} ; 34.89$ ppm; $110 \mathrm{~m}$ depth; sand and stones; IINH-40473 - 17 specs; BIOICE station 17, sample 2660; 67 $14^{\prime} 41^{\prime \prime} \mathrm{N}$, $15^{\circ} 28^{\prime} 42^{\prime \prime} \mathrm{W} ; 15 \mathrm{Jul}$. 1994; $2.69^{\circ} \mathrm{C}$; 34.90 ppm; $277 \mathrm{~m}$ depth; sandy silt; IINH-40474 • 5 specs; BIOICE station 5, sample 3108; 67 $45^{\prime} 48^{\prime \prime} \mathrm{N}, 18^{\circ} 30^{\prime} 85^{\prime \prime} \mathrm{W} ; 21$ Aug. $1999 ;-0.21^{\circ} \mathrm{C} ; 34.88 \mathrm{ppm} ; 328 \mathrm{~m}$ depth; sediment unknown; IINH-40475 • 23 specs; BIOICE station 23, sample 3249; 65'50'34" N, 12 $011^{\prime} 27^{\prime \prime} \mathrm{W}$; 14 Jul. 2001; $1.92^{\circ} \mathrm{C} ; 34.87$ ppm; $192 \mathrm{~m}$ depth; sediment unknown; IINH-40476 24 specs; BIOICE station 24 , sample $3252 ; 65^{\circ} 45^{\prime} 94^{\prime \prime} \mathrm{N}, 12^{\circ} 16^{\prime} 39^{\prime \prime} \mathrm{W} ; 14$ Jul. $2001 ; 1.48^{\circ} \mathrm{C} ; 34.86$ ppm; $232 \mathrm{~m}$ depth; sediment unknown; IINH-40477.

\section{Occurrence}

From off northern and north-eastern coast of Iceland (Fig. 1D). Depth range: 26 to $328 \mathrm{~m}$; bottom temperature range: -0.21 to $6.00^{\circ} \mathrm{C}$ (Fig. 2D). Water mass/es: NSAIW, CW and MNAW.

\section{Remarks}

Cistenides hyperborea - type locality: Greenland and Spitzbergen (Holthe 1986) - is a poorly known species; the original description does not indicate the number of rows of teeth present on the uncini, although 1 to 3 rows have previously been mentioned for specimens assigned to this taxon (Hutchings \& Peart 2002). Because type material was never designated (Holthe 1986), Hutchings \& Peart (2002) suggested that specimens from the type locality need to be re-examined to ascertain the generic identity of this species.

The examination of the Icelandic specimens here identified as $C$. hyperborea, covering a wide range of body sizes, shows a considerable variation in the shape of the neuropodial uncini, contrary to the expected, according to the description of the species. BIOICE specimens agree with previous descriptions (e.g., Pettibone 1954; Holthe 1986; Hutchings \& Peart 2002) in: 1) having a smooth dorsal brim and cephalic veil free from operculum, provided with several well-defined cirri (Fig. 10A); 2) the relation between chaetigers with notochaetae versus those with also ventral uncini is $17 / 12 ; 3$ ) the paleae are long, numerous, straight and with pointed tips (Figs 10A, 12A); 4) the scaphe has small lateral lobes (Fig. 11A) with a short and rounded anal lobe and anal papilla (Fig. 11B), and scaphal hooks are distally bent (Fig. 11C-E). On the other hand, the aforementioned characters show, however, differences related to the size of the specimen. For instance, medium-sized and small individuals show a strait scaphe border with a verrucose anal lobe (Fig. 11E-F), thinner paleae (Figs 12A, 13A) and the tip of the scaphal hooks is strongly curved (compare Figs 12F, 13F, 14F).

The number and arrangement of teeth in the neuropodial uncini shows differences among BIOICE individuals, contrary to that observed in C. granulata. Two different types of uncini can be distinguished:

1) Uncini with 2-3 main teeth arranged in a vertical row. This is the typical teeth arrangement in the pectinate type for this species and the genus as well. We found this pattern in large specimens (Figs 3D, 10).

2) Uncini provided with a large basal tooth (rostrum) and an upper group of short teeth (capitium). This agrees with the typical avicular type present in many species of Terebellomorpha and found here in smaller specimens (Figs 3D, 12-13).

SEM examination of BIOICE specimens seems to support the hypothesis that these differences are related to body size even though we did not examine the whole range of sizes (Fig. 3D). Uncini of large specimens (sample 3252, Fig. 10) do not show a variation either within an individual torus or along the body; on the contrary, mid-sized specimens (sample 2660, Fig. 12) show a progressive increase in the number of upper teeth, mostly in ventral uncini (Fig. 12C, E) and especially in posterior chaetigers (Fig. 12E), the latter having a well-defined capitium; dorsal uncini show, in turn, the usual shape as 


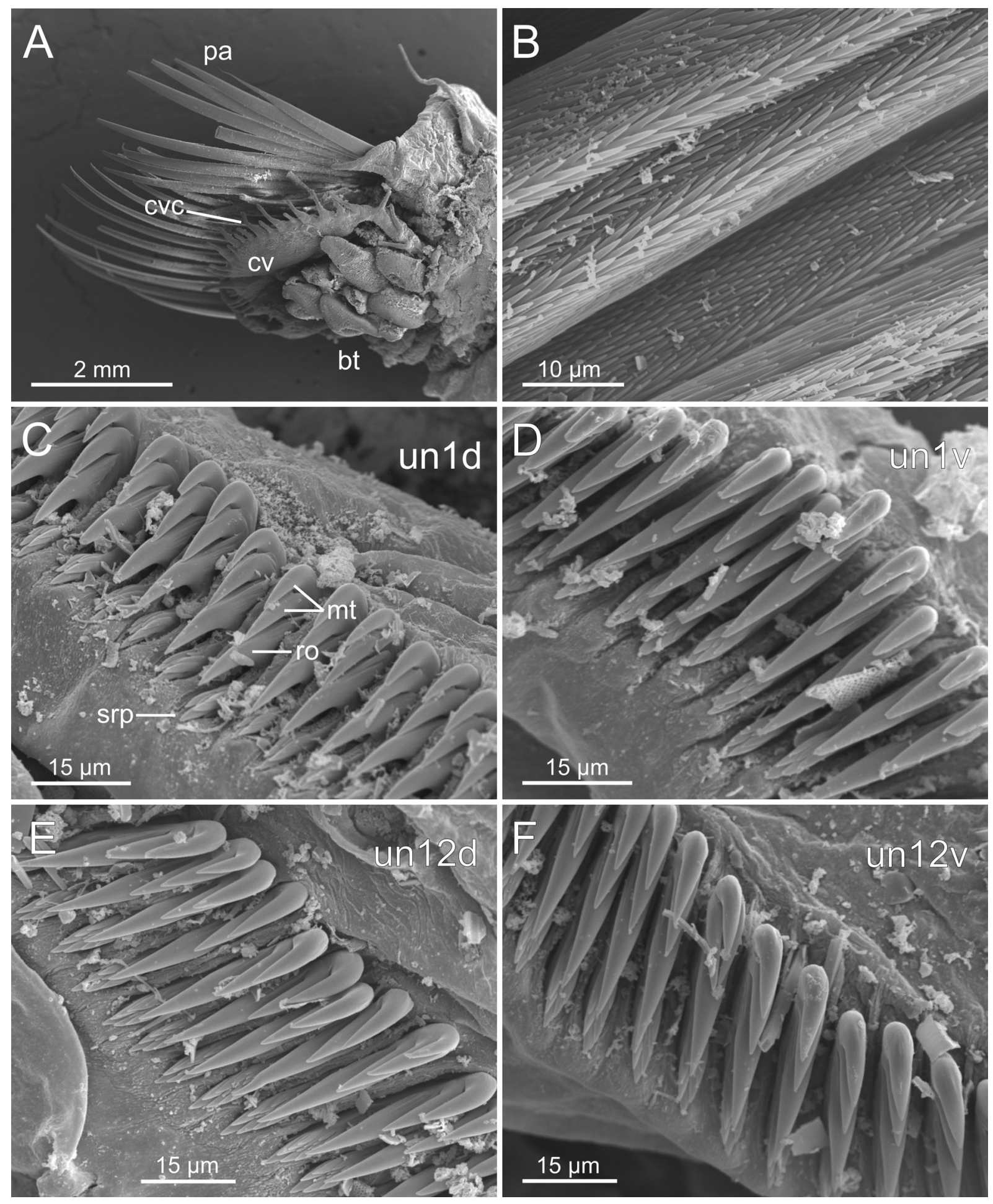

Fig. 10. Cistenides hyperborea Malmgren, 1866. SEM micrographs from three large specimens (BIOICE sample 3252, IINH-40477). A. Anterior end, left ventrolateral view. B. Notochaetal scale covering, detail. C-D. Unciniger 1, dorsal and ventral uncini, respectively. E-F. Unciniger 12, dorsal and ventral uncini, respectively. 

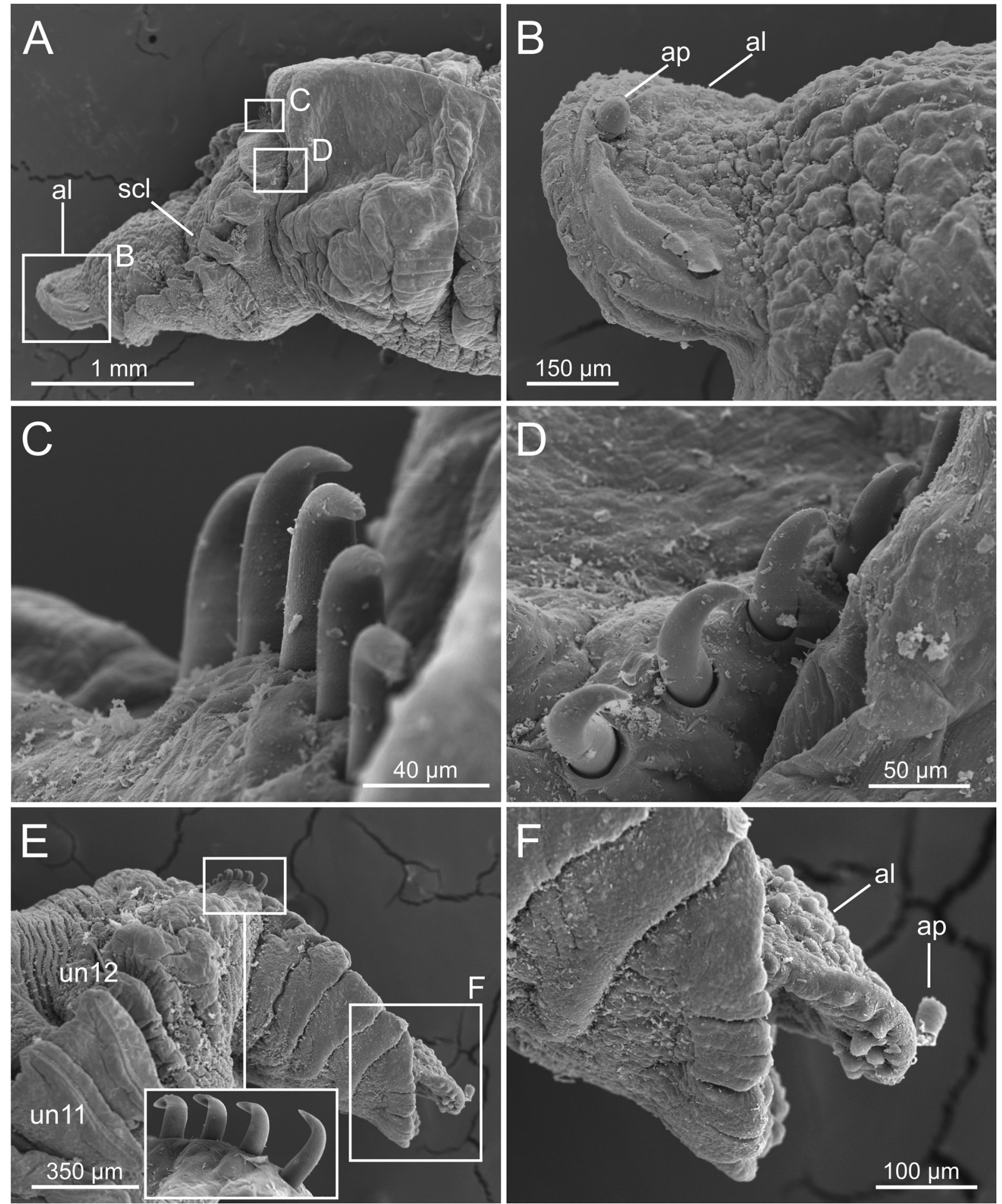

Fig. 11. Cistenides hyperborea Malmgren, 1866. SEM micrographs from four large specimens (AD: BIOICE sample 3252, IINH-40477; E-F: sample 3249, IINH-40476). A. Scaphe, left lateral view. B. Anal lobe and anal papilla (framed in A). C-D. Scaphal hooks (framed in A). E. Posterior end (framed: scaphal hooks, detail). F. Scaphe and anal lobe and papilla (framed in E). 

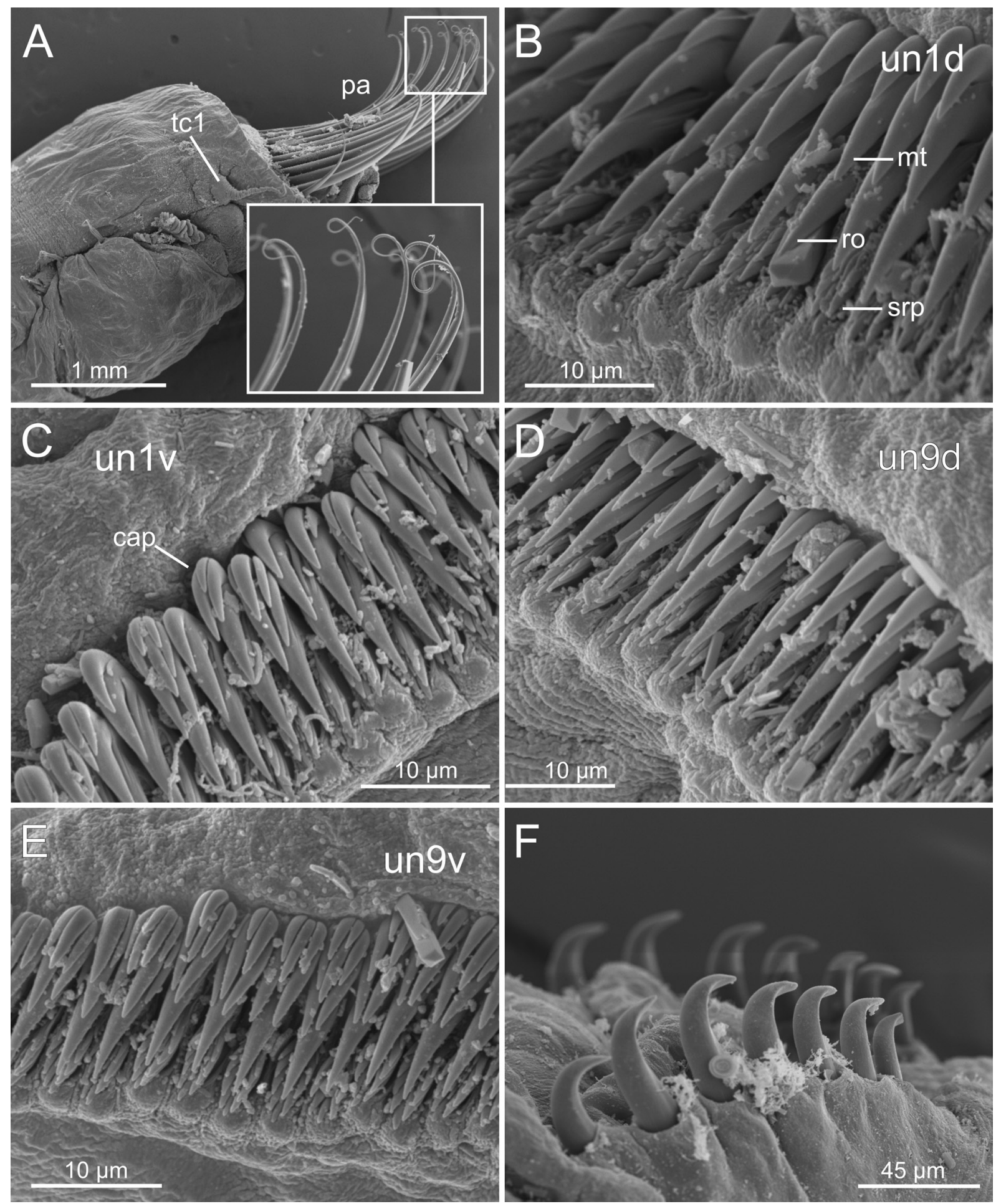

Fig. 12. Cistenides hyperborea Malmgren, 1866. SEM micrographs from a medium-sized specimen (BIOICE sample 2660, IINH-40474). A. Anterior end, right lateral view (framed: paleae distal end, detail). B-C. Unciniger 1, dorsal and ventral uncini, respectively. D-E. Unciniger 9, dorsal and ventral uncini, respectively. F. Scaphal hooks. 
PARAPAR J. et al., Taxonomy and distribution of Pectinariidae (Annelida) from Iceland
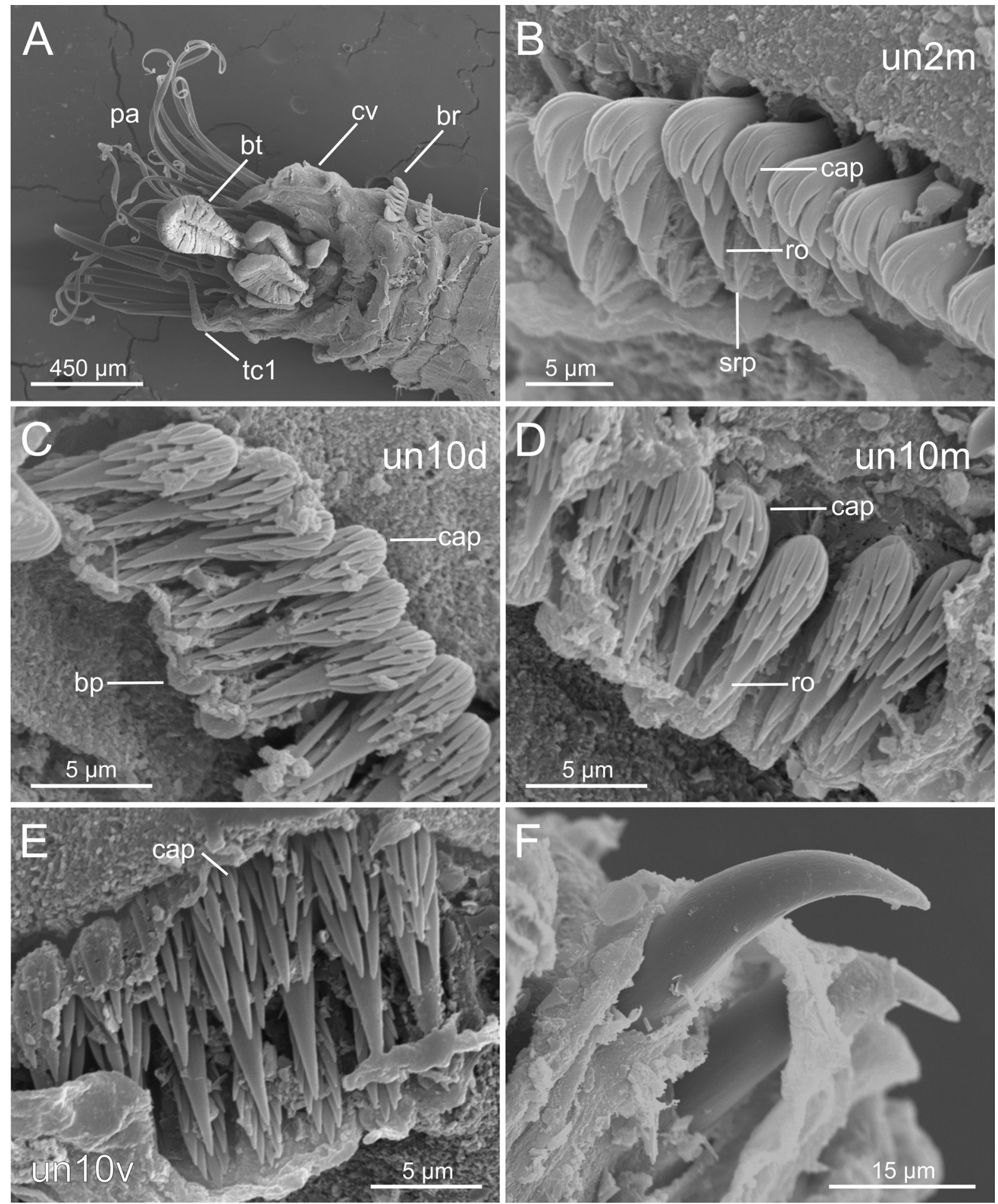

Fig. 13. Cistenides hyperborea Malmgren, 1866. SEM micrographs from a small specimen (BIOICE sample 2041, IINH-40470). A. Anterior end, ventral view. B. Unciniger 2, median uncini. C-E. Unciniger 10, dorsal, median and ventral uncini, respectively. F. Scaphal hooks. 

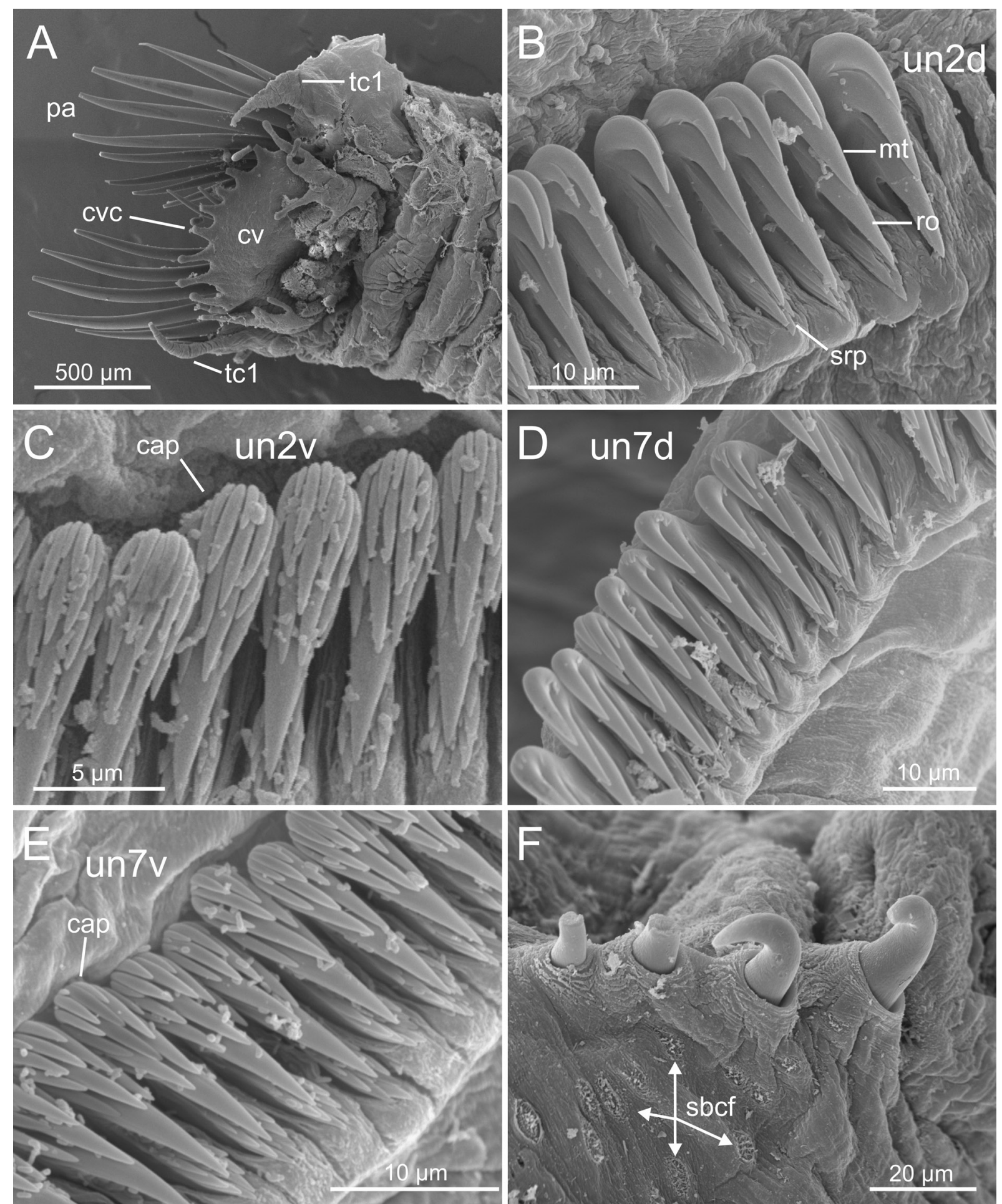

Fig. 14. Cistenides hyperborea Malmgren, 1866. SEM micrographs from two medium-sized specimens (BIOICE sample 2060, IINH-40471). A. Anterior end, ventral view. B-C. Unciniger 2, dorsal and ventral uncini, respectively. D-E. Unciniger 7, dorsal and ventral uncini, respectively. F. Scaphal hooks and scaphal basis ciliary patches. 
PARAPAR J. et al., Taxonomy and distribution of Pectinariidae (Annelida) from Iceland
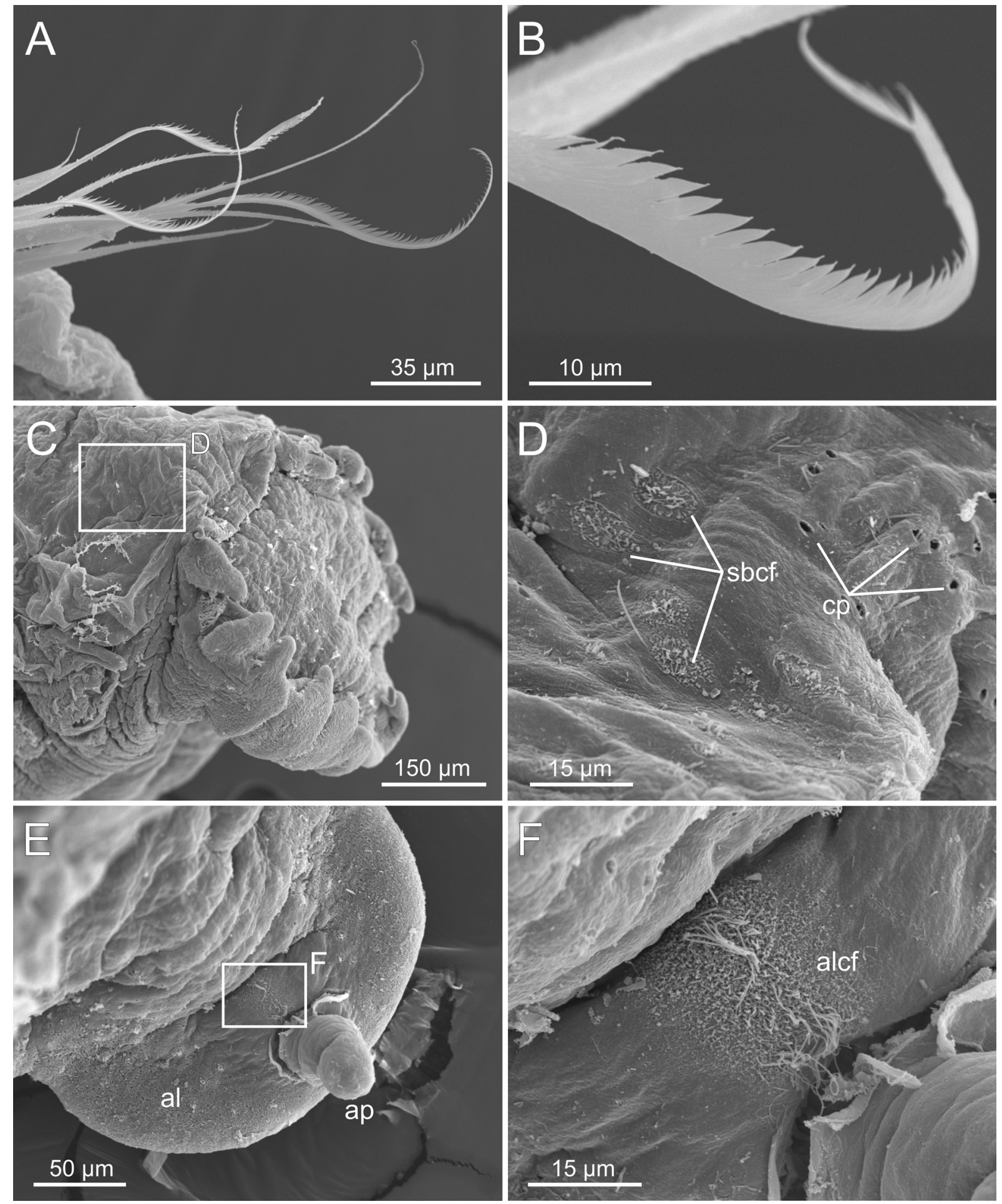

Fig. 15. Cistenides hyperborea Malmgren, 1866. SEM micrographs from two medium-sized specimens (BIOICE sample 2060, IINH-40471). A. Mid-body parapodium, notochaetae. B. Notochaeta, serrated distal end, detail. C. Scaphe, dorso-lateral view. D. Cuticular structures (framed in C). E. Anal lobe and anal papilla. F. Ciliary field dorsal to anal lobe (framed in E). 
found in the genus (Fig. 12B, D). This pattern of variation is more evident in small specimens (sample 2041, Fig. 13), where the dorsal uncini are also of avicular type (Fig. 13B-D), similar to ventral ones (Fig. 13E). Therefore, these results suggest that the BIOICE specimens of $C$. hyperborea show changes in the uncini shape during ontogenetic development and that the uncini type varies accordingly depending on the age of the specimen. This variation, as explained above, occurs within a torus and along the body; thus, as small specimens with the avicular type of uncini grow, and uncini are being replaced along the torus, there is a progressive decrease in the number of upper teeth and a loss of the rostrum finally resulting in a pectinate type with the typical formula of the genus (i.e., MF:1:1:1).

Specimens from sample 2060 (Fig. 2D) found in a shallow bottom (48 m) in North Iceland, were also identified as C. hyperborea. Nevertheless, they show thicker paleae (cf. Fig. 14 vs Fig. 13) than similarsized specimens from other samples, and dorsal uncini are similar to those of larger specimens found elsewhere (Fig. 14B, D), while ventral ones (Fig. 14C, E) correspond to those of specimens of their size such as those of sample 2660 (Fig. 12C, E). Finally, scaphe hooks appear more strongly curved than would be expected for this species (cf. Fig. 14F vs Figs 11E, 12F, 13F). Therefore, this variation suggests that specimens from sample 2060 may correspond to another species (probably undescribed yet) within a potential species complex present in NE Atlantic waters, that should be assessed in future in combination with molecular studies.

Finally, SEM micrographs show that the tip of the notochaetae is serrated (Fig. 15A-B), and reveal the presence of perforations in the cuticle of the dorsal region anterior to the scaphe (Fig. 15C-D) and of two types of ciliated fields: 1) rounded fields located before the scaphe and among the cuticular perforations (Fig. 15C-D) and 2) one large field located dorsal to the anal lobe and anterior to the anal papilla (Fig. 15E-F). These fields may be related to water irrigation, but certainly a future in-depth study is necessary.

Genus Lagis Malmgren, 1866

\section{Type species and type locality}

Lagis koreni Malmgren, 1866. Finnmark (Norway), lectotype in Naturhistoriska Riksmuseet, Stockholm, designated by Nilsen et al. (1977) (see Holthe 1986).

\section{Remarks}

The diagnosis of the genus by Hutchings \& Peart (2002) states that neurochaetal uncini have large teeth arranged in two or more rows. Examination of BIOICE specimens of L. koreni shows again that there are changes in teeth shape with increasing size of an individual, reflected in a progressive reduction in the number of teeth rows with the age of the animal. This still fits the diagnosis of the genus ("two or more rows") but a better definition of uncini shape is needed. In contrast to the other species studied here, the uncini are, in all body sizes studied, of the pectinate type (see below).

Lagis koreni Malmgren, 1866

Figs 1B, 2B, 3B, 4I-L, 16-17

Lagis koreni Malmgren, 1866: 360.

Pectinaria koreni- Hessle 1917: 80.

Pectinaria (Lagis) koreni - Fauvel 1927: 221. — Holthe 1986: 18. — Hartmann-Schröder 1996: 483.

— Kirkegaard 1996: 283. 
PARAPAR J. et al., Taxonomy and distribution of Pectinariidae (Annelida) from Iceland
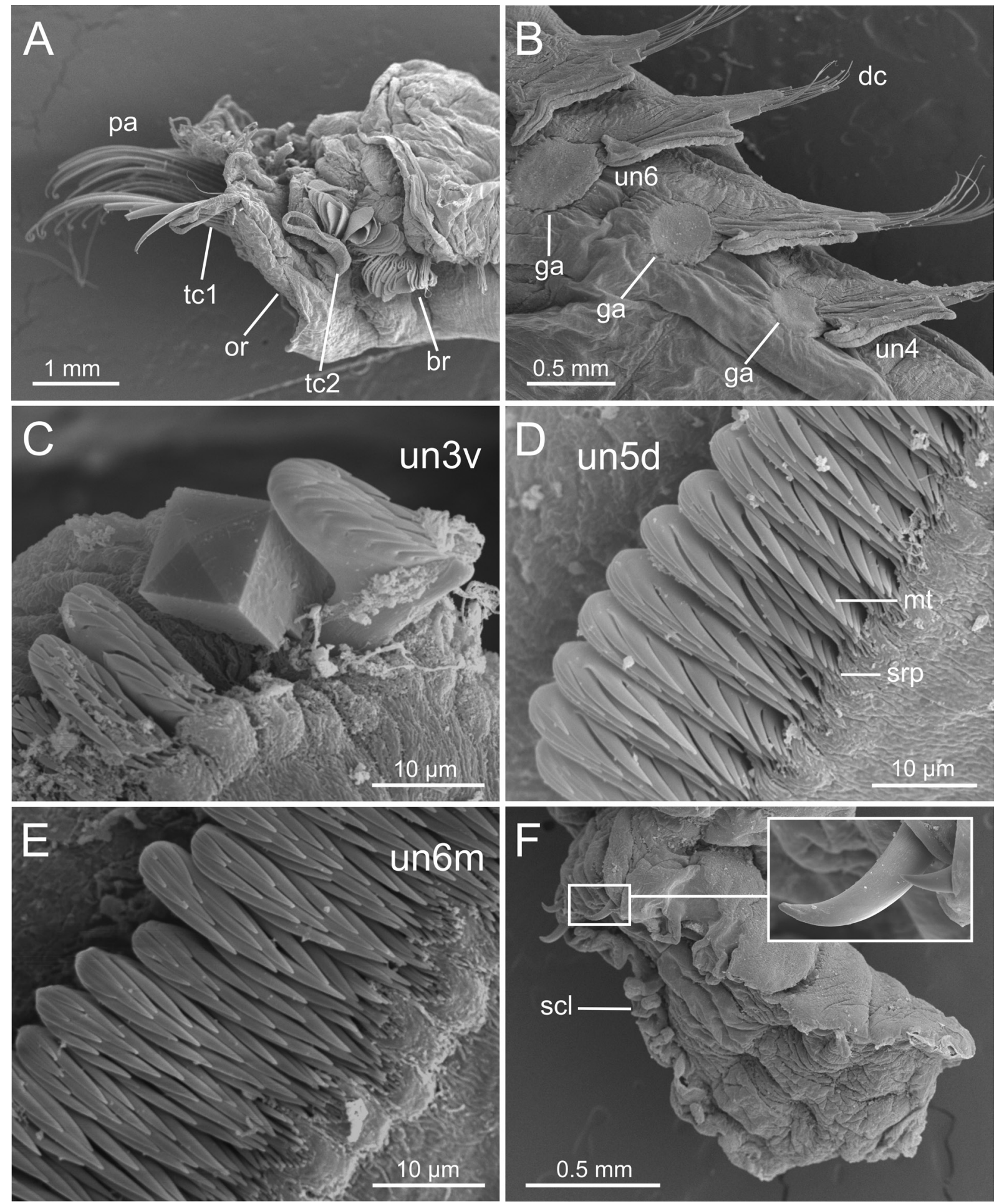

Fig. 16. Lagis koreni Malmgren, 1866. SEM micrographs from two specimens: large (A, F) and medium sized (B-E), respectively (BIOICE sample 2827, IINH-40485). A. Anterior end, right lateral view. B. Uncinigers 4 to 6, ventrolateral view. C. Unciniger 3, ventral uncini. D. Unciniger 5, dorsal uncini. E. Unciniger 6, median uncini. F. Scaphe and scaphal hooks (framed: scaphal hook, detail). 
Material examined ( 801 specimens, $75.1 \%$ of total specimens identified, in ten samples)

ICELAND - North Western Fjords - 1 spec.; BIOICE station 31, sample 2557; 66 $21^{\prime} 90^{\prime \prime} \mathrm{N}$, $23^{\circ} 04^{\prime} 93^{\prime \prime}$ W; 14 Jul. 1993; 7.23두 34.34 ppm; 20 m depth; sand; IINH-40483. - South coast • 1 spec.;

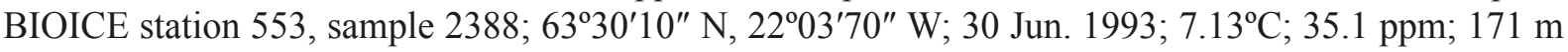

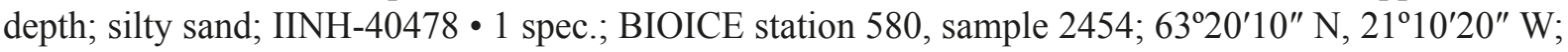
4 Jul. $1993 ; 7.19^{\circ} \mathrm{C} ; 35.08$ ppm; $152 \mathrm{~m}$ depth; sediment unknown; MNCN 16.01/18034 3 specs; BIOICE

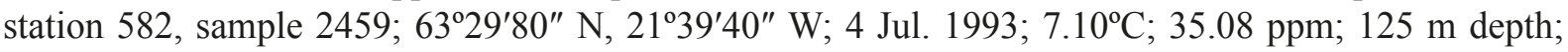
silt; IINH-40480 - 3 specs; BIOICE station 583, sample 2463; 6325'40" N, 2139'89" W; 5 Jul. 1993; $7.12^{\circ} \mathrm{C}$; $35.08 \mathrm{ppm} ; 133 \mathrm{~m}$ depth; silty sand and gravel; IINH-40481 6 specs; BIOICE station 588,

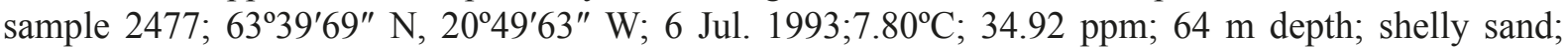

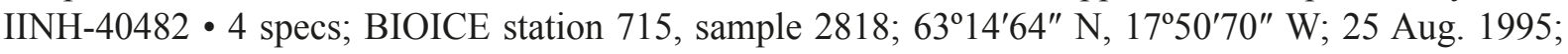
$7.18^{\circ} \mathrm{C}$; $35.14 \mathrm{ppm} ; 206 \mathrm{~m}$ depth; silty sand; IINH-40484 - 770 specs; BIOICE station 718, sample 2827; $63^{\circ} 41^{\prime} 00^{\prime \prime} \mathrm{N}, 17^{\circ} 39^{\prime} 90^{\prime \prime} \mathrm{W} ; 25$ Aug. 1995; $8.79^{\circ} \mathrm{C} ; 34.77$ ppm; 44 m depth; sandy silt; IINH-40485 •

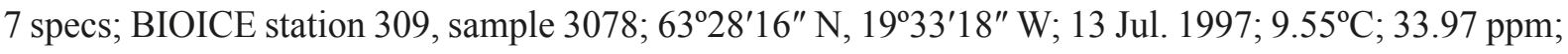
$21 \mathrm{~m}$ depth; sediment unknown; IINH-40486 • 5 specs; BIOICE station 726, sample 3257; 63⒉ $20^{\prime} 10^{\prime \prime} \mathrm{N}$, $19^{\circ} 52^{\prime} 20^{\prime \prime} \mathrm{W} ; 11$ Sep. 2001; $7.92^{\circ} \mathrm{C}$; 35.19 ppm; $221 \mathrm{~m}$ depth; sediment unknown; IINH-40487.

\section{Occurrence}

Off south-western coast of Iceland (Fig. 1B). Depth range: 20 to $221 \mathrm{~m}$; bottom temperature range: 7.10 to $9.55^{\circ} \mathrm{C}$ (Fig. 2B). The shallowest sample $(2557 ; 20 \mathrm{~m})$ was found in north-western fjords. The easternmost sample $(2827 ; 44 \mathrm{~m})$ contains the highest number of pectinariid specimens found in any BIOICE sample (770; 96.5\%) ). Water mass/es: MNAW.

\section{Remarks}

Body and chaetal features match well those of L. koreni provided by Holthe (1986), including the shape and number of paleae (Figs 4I, K, 16A, 17A), smooth opercular rim (Fig. 4I, K), cirrate cephalic veil (Fig. 17A-B), a crenulated scaphe (Fig. 16F) provided with slightly distally curved hooks (Figs 16F insert, 17F), and 16 uniramous and 12 biramous segments (see Holthe 1986). However, SEM examination again reveals differences between the uncini features and those reported in the literature, that seem related to morphological variability according to size/age. Large and mid-sized specimens (Fig. 16C-E) bear uncini as described in the literature, i.e., having 3-4 vertical rows with many teeth (6-8) of similar size each and showing no variation across the body or within an individual torus; by contrast, uncini of small specimens (Fig. 17C-E) have more rows of teeth (5-7) in frontal view (Fig. 16E vs Fig. 17D-E).

Finally, SEM micrographs also show circular areas under the parapodia with segmentary arrangement (Fig. 16B); these are likely nephridial or glandular and may have a role in tube building, although this should be confirmed in future morphological studies.

\section{Key to NE Atlantic species of Pectinariidae}

The key below is based on Gil (2011), who, in turn, adapted those from Fauchald (1977), Holthe (1986) and Hutchings \& Peart (2002), and is also complemented with recent papers such as Nishi et al. (2014), Zhang \& Qiu (2017), Nogueira et al. (2019) and Zhang et al. (2019).

Several features concerning morphological changes of uncini related to growth as commented above are included. A formula confronting the number of chaetigers with only notopodia or dorsal chaetae (dc) vs those with biramous parapodia or also with ventral uncini (vu) is included as a key character for discriminating between genera. This is referred mostly for Icelandic specimens because of the many inconsistencies found in the literature across species (see Discussion). 
PARAPAR J. et al., Taxonomy and distribution of Pectinariidae (Annelida) from Iceland
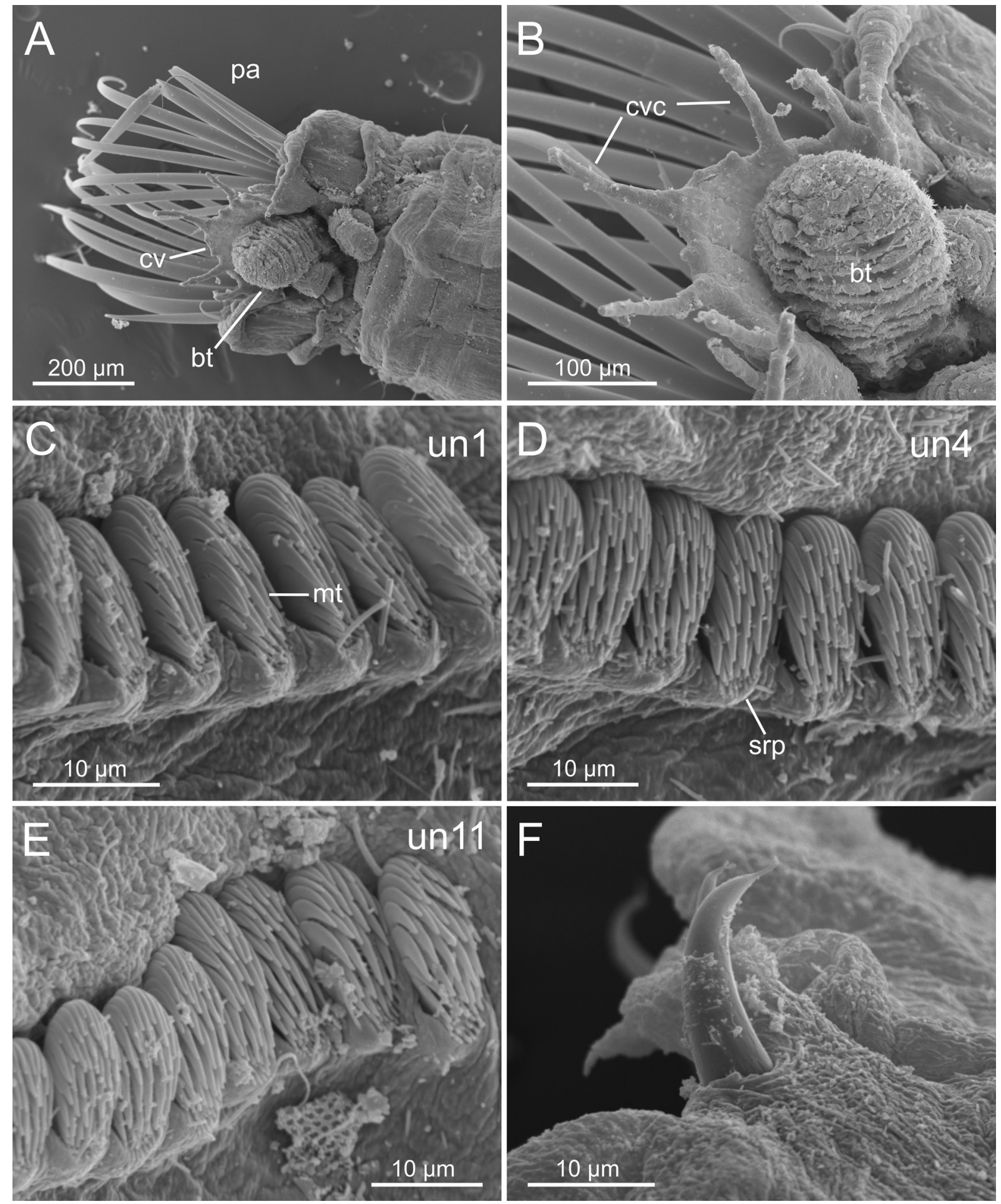

Fig. 17. Lagis koreni Malmgren, 1866. SEM micrographs of a small specimen (BIOICE sample 3078, IINH-40486). A. Anterior end, ventral view. B. Cephalic veil, detail. C-E. Uncinigers 1, 4 and 11, uncini. F. Scaphal hook. 
1. Cephalic veil (tentacular membrane) smooth; scaphe indistinctly separated from abdomen; $\mathrm{dc} / \mathrm{vu}=$ 17/14 (Petta) .

- Cephalic veil cirrate; scaphe distinctly separated from abdomen; dc/vu not 17/14 2

2. Opercular rim with cirri (serrated) or lappets; $\mathrm{dc} / \mathrm{vu}=17 / 13$ (Amphictene).

Amphictene auricoma (O.F. Müller, 1776)

- Opercular rim smooth; $\mathrm{dc} / \mathrm{vu}=17 / 13$ or different

3. Cephalic veil attached to lateral margin of opercular rim; $\mathrm{dc} / \mathrm{vu}=16 / 12$ (Lagis)

Lagis koreni Malmgren, 1866

- Cephalic veil free from opercular rim; de/vu not 16/12

4. Uncini with more than one longitudinal row of major teeth in well-developed specimens; $\mathrm{dc} / \mathrm{vu}=$ 17/13 (Pectinaria). Pectinaria belgica (Pallas, 1766)*

- Uncini with only one longitudinal row of major teeth in well-developed specimens; dc/vu =17/12 (Cistenides).....

5. Paleae short, with blunt tips; all uncini of pectinate type, with one vertical row of teeth, no dorsoventral variation in same unciniger or along the body..... Cistenides granulata (Linnaeus, 1767)

- Paleae long, with pointed tips; uncini shape avicular type in small and medium-sized specimens showing dorso-ventral variation; pectinate type (single vertical row of teeth) within the same chaetiger and along the body in large ones Cistenides hyperborean Malmgren, 1866

${ }^{*}$ Species not found in BIOICE samples.

\section{Discussion}

Hutchings \& Peart (2002), in their revision of the Australian Pectinariidae, stated that "Individuals belonging to the Pectinariidae are easy to recognise, but the systematics of this widely distributed family has been neglected. The confused identity of the common European species suggests that many species may have been misidentified or perhaps several species confused under one name". This is also true for the NE Atlantic fauna, where the most recent monograph was provided by Holthe (1986); this contrasts with other areas such as China, Brazil and Australia where knowledge on the family has substantially been improved recently (e.g., Sun \& Qiu 2012; Zhang \& Qiu 2017; Zhang et al. 2015, 2019; Nogueira et al. 2019).

\section{Abundance, geographical and bathymetric distribution}

Among the BIOICE material, L. koreni was the most abundant species (> 75\%) followed by A. auricoma and then by the two species of Cistenides. These results agree with those in previous works for the NE Atlantic (e.g., Holthe 1986; Hartmann-Schröder 1996; Gil 2011). Each species mostly shows a homogenous geographic and bathymetric distribution including water temperature, but species of Cistenides show slightly wider ranges; the latter are mostly distributed in northern, colder water masses (Figs 1B-C, 2B-C) while A. auricoma and L. koreni are found in warmer Atlantic waters (see Hansen \& Østerhus 2000; Brix \& Svavarsson 2010; Meißner et al. 2014).

\section{Uncinal morphology}

The Terebellomorpha and other tubiculous polychaetes have hook-like neurochaetae (i.e., uncini) that allow for the movement of the worm inside the tube (Woodin \& Merz 1987; Merz \& Woodin 2000). Previous works such as Hutchings \& Glasby (1988), Glasby \& Glasby (2006) and Nogueira et al. (2010) reported on the variation of their shape during ontogeny in several genera of Terebellidae (e.g., Polycirrus Grube, 1850 and Loimia Malmgren, 1866). Thus, uncini of fully-grown specimens bear a 
vertical series of teeth while in young ones there is a large number arranged in transverse series. The aforementioned authors also affirm that the extent of this variability, both within the same neuropodial row and between segments along the body, has never been widely appreciated, although Duchène \& Bhaud (1988) previously reported similar patterns in six terebellid species. Because of that, and its apparent correlation with other relevant taxonomic characters, Glasby \& Glasby (2006) proposed to consider these variations in future phylogenetic studies of the group. Garraffoni \& Camargo (2006) also stated that Terebellidae uncini "... is a rich source of taxonomic information that can be used to help assess evolutionary relationships within the family". Our study demonstrates that this approach should be extended to the Pectinariidae in general, and especially to the genus Cistenides.

Recently, Nogueira et al. (2019), following Hutchings \& Peart (2002), considered the uncini of Cistenides as being "pectinate, with single longitudinal row of teeth" and reported for the first time in the family the presence of avicular uncini when diagnosing the genus Petta: "the uncini are breviavicular rather than bipectinate (sensu Holthe 1986), with transverse series of progressively shorter distal wards secondary teeth on top of the main fang." (Nogueira et al. 2019: 491). Our observations suggest that: 1) in Cistenides the uncini type change as the specimen grows, and this should be considered in the diagnosis of the genus; 2) the presence of avicular uncini in Petta should be also confirmed in small specimens; 3) avicular uncini are not exclusive of Petta but are also present in Icelandic specimens of $C$. hyperborea as demonstrated here for young specimens of the latter. Nogueira et al. (2019) also pointed out that SEM examination is needed to truly assess the uncini features, by comparing SEM micrographs of Petta alissoni Nogueira et al., 2019 with those obtained with light microscope (cf. Nogueira et al., 2019: fig. 11d vs fig. 12f-g). Thus, images obtained with the latter show similar uncini to those described and illustrated by Holthe (1986: fig. 7f) as having a "rostrum surmounted by a large tooth", but the use of SEM demonstrated that this is a wrong interpretation of the actual uncini shape. Unfortunately, specimens of Petta pusilla Malmgren, 1866, the type species of the genus, were not found among the BIOICE material in order to test this hypothesis and therefore future work is needed to address this.

\section{Dorsal chaetae versus ventral uncini (dc/vu)}

Again, following Hutchings \& Peart (2002), some generic characters seem to overlap in Pectinariidae, and therefore it seems advisable to find additional diagnostic elements. In fact, these authors propose to include the number of uniramous vs biramous segments, i.e., the number of chaetigers with dorsal chaetae (dc) vs those with ventral uncini (vu), suggesting the following values for each genus: Amphictene (17/13), Cistenides (17/13), Lagis (16/12), Pectinaria (17/13) and Petta (18/14), although they recognize that the validity of this character needs further testing because some species have reduced posterior notopodia that may easily be overlooked. The study of BIOICE specimens of Cistenides confirms the actual number of chaetigers with thoracic notochaetae (17), but we also suggest to modify the number of neuropodial uncinigerous tori from 12 to 13 (see below).

\section{Other taxonomical characters}

Hutchings \& Peart (2002) include the character "notochaetal ornamentation" among those most relevant for Pectinariidae genera; in the case of Cistenides, this feature was not described. Our examination of C. granulata and C. hyperborea reveals that the distal half of the notochaetae is clearly serrated and this should be added to the genus diagnosis. The same authors also stated that the actual size of the opercular paleae may not be diagnostic because they may be worn by digging and can presumably be replaced during life. From our examination of BIOICE specimens we think that, even considering that the distal end may be worn, other characters remain unchanged during development, including length, width or shape of distal end of paleae. In fact, the paleal general shape is proposed here as a reliable cue to recognize potential different species of $C$. hyperborea. 


\section{Delimitation of genera}

Following Hutchings \& Peart (2002), the characters traditionally used to separate the pectinariid genera are: 1) the degree of fusion of the cephalic veil to the operculum; 2) the marginal ornamentation of the cephalic veil and the operculum; 3) the number of uncinigerous segments; 4) the number of vertical rows of teeth on the uncini, and 5) the degree of separation of the scaphe from the abdomen. As we noted above, Hutchings \& Peart (2002) also included details of the notochaetae for the genera represented in Australian waters.

Hutchings \& Peart (2002) diagnozed the genus Cistenides as having 13 uncinigers and proposed to transfer several species to Pectinaria because of having two rows of teeth in uncini instead of one. Following Gil (2011), the genus Cistenides as erected by Malmgren (1866) was originally diagnosed as having 12 uncinigers; this diagnosis was followed by many authors such as Fauvel (1927) and Annenkova (1929) and is also followed here. Gil (2011) revised the descriptions of the species attributed by Hutchings \& Peart (2002) to this genus (some described as having 13 uncinigers while others with 12), and considered that the genus should be referred as presenting 12-13 uncinigers; however, Gil (2011) also provided a key for pectinariid genera where Cistenides is characterized as having 12 uncinigers and Pectinaria 13 because this condition was found in specimens of both European species of this genus (both present in BIOICE material), one of them being C. granulata, the type species of the genus.

Gil (2011) agrees with Hutchings \& Peart (2002) in considering the number of rows of teeth in the uncini as a relevant diagnostic character at the genus level and thus uncini of Cistenides would have large teeth arranged in 1-2 rows. In this context, we suggest that this character only corresponds to large specimens and until the ontogeny of all species of Pectinariidae is known, the shape of the uncini should be used with caution when separating genera and species.

It is likely that an in-depth revision of the family in the NE Atlantic, including a molecular approach, may reveal a higher diversity. For instance, Jolly et al. (2005) observed different patterns of genetic structure in different populations for L. koreni along Brittany and the English Channel; they found a "surprisingly deep phylogeographic break" which was associated with a biogeographic boundary along the western coast of Brittany and suggested the occurrence of potential cryptic or sibling species. In the same vein, Nygren et al. (2018) demonstrated the presence of more than 25 species of the genus Terebellides Sars, 1835 (Trichobranchidae) along the NE Atlantic coast.

\section{Acknowledgements}

The senior author wishes to thank Gudmundur Gudmundsson, Director of Collections and Systematics Department, Náttúrufræðistofnun Íslands (Icelandic Institute of Natural History) for the loan of the specimens. Special thanks to all the people involved in sorting of specimens from the BIOICE samples in the SMC. Ada Castro and Catalina Sueiro (SAIN, UDC) assisted in the preparation of specimens. This study was partly supported by the Fauna Ibérica research project (Polychaeta VII, Palpata, Canalipalpata II - PGC2018-095851-B-C64) to J. Parapar and J. Moreira. The Bibliographic Service of the Universidade da Coruña is also thanked for providing useful bibliography. Authors would like to thank the reviewers Pat Hutchings and Joao Miguel de Matos Nogueira as well as the topical and desk editors of EJT Rudy Jocqué and Kristiaan Hoedemakers for their constructive comments on the manuscript.

\section{References}

Annenkova N.P. 1929. Beiträge zur Kenntnis der Polychaeten-Fauna der USSR. I. Fam. Pectinariidae Quatrefages (Amphictenidae Malmgren) und Ampharetidae Malmgren. Annuaire du Musée zoologique 
PARAPAR J. et al., Taxonomy and distribution of Pectinariidae (Annelida) from Iceland

de l'Académie des Sciences de l'URSS [Ezhegodnik Zoologicheskogo Museya] AN SSSR 30 (3): 477502.

Brix S. \& Svavarsson J. 2010. Distribution and diversity of desmosomatid and nannoniscid isopods (Crustacea) on the Greenland-Iceland-Faeroe Ridge. Polar Biology 33: 515-530.

https://doi.org/10.1007/s00300-009-0729-8

Chambers S.J. \& Woodham A. 2003. A new species of Chaetozone (Polychaeta: Cirratulidae) from the deep water in the northeast Atlantic, with comments on the diversity of the genus in cold northern waters. Hydrobiologia 496: 41-48. https://doi.org/10.1023/A:1026116008735

Day J.H. 1967. A Monograph on the Polychaeta of Southern Africa. British Museum of Natural History Publication 656. Trustees of the British Museum (Natural History), London.

https://doi.org/10.5962/bhl.title.8596

Duchène J.C. \& Bhaud M. 1988. Uncinial patterns and age determination in terebellid polychaetes. Marine Ecology Progress Series 49: 267-275. https://doi.org/10.3354/meps049267

Fauchald K. 1977. The polychaete worms. Definitions and keys to the orders, families and genera. Natural History Museum of Los Angeles County, Science Series 28: 1-188.

Fauvel P. 1927. Polychètes sédentaires. Addenda aux errantes, archiannélides, myzostomaires. Faune de France 16: 1-494.

Garraffoni A.R.S. \& Camargo M.G. 2006. First application of morphometrics in a study of variations in uncinal shape present within the Terebellidae (Polychaeta). Zoological Studies 45 (1): 75-80.

Gil J. 2011. The European Fauna of Annelida Polychaeta. PhD Thesis, Universidade de Lisboa, Portugal.

Glasby C.J. \& Glasby T.M. 2006. Two types of uncini in Polycirrus (Polychaeta: Terebellidae: Polycirrinae) revealed using geometric morphometrics. Journal of Natural History 40 (5-6): 237-253. https://doi.org/10.1080/00222930600627137

Hansen B. \& Østerhus S. 2000. North Atlantic-Nordic Seas exchanges. Progress in Oceanography 45: 109-208. https://doi.org/10.1016/S0079-6611(99)00052-X

Hartman O. 1941. Polychaetous annelids. Part IV. Pectinariidae. Allan Hancock Pacific Expeditions 7: $325-345$.

Hartmann-Schröder G. 1971. Annelida, Borstenwürmer, Polychaeta. Die Tierwelt Deutschlands 58, $1^{\text {st }}$ ed. Gustav Fischer, Jena.

Hartmann-Schröder G. 1996. Annelida, Borstenwürmer, Polychaeta. Die Tierwelt Deutschlands 58, $2^{\text {nd }}$ ed. Gustav Fischer, Jena.

Hessle C. 1917. Zur Kenntnis der terebellomorphen Polychaeten. Zoologiska Bidrag från Uppsala 5: $39-258$.

Holthe T. 1986. Polychaeta Terebellomorpha. Marine Invertebrates of Scandinavia 7, Norwegian University Press, Oslo.

Hutchings P. 2000. Family Pectinariidae. In: Beesley P.L., Ross G.J.B. \& Glasby C.J. (eds) Polychaetes \& Allies: The Southern Synthesis. Fauna of Australia. Vol. 4A. Polychaeta, Myzostomida, Pogonophora, Echiura, Sipuncula: 294-299. CSIRO Publishing, Melbourne.

Hutchings P.A. \& Glasby C.J. 1988. The Amphitritinae (Polychaeta: Terebellidae) from Australia. Records of the Australian Museum 40 (1): 1-60. https://doi.org/10.3853/j.0067-1975.40.1988.150 
Hutchings P.A. \& Peart R. 2002. A review of the genera of Pectinariidae (Polychaeta) together with a description of the Australian fauna. Records of the Australian Museum 54: 99-127. https://doi.org/10.3853/j.0067-1975.54.2002.1356

Jirkov I.A. \& Leontovich M.K. 2013. Identification keys for Terebellomorpha (Polychaeta) for the Eastern Atlantic and the North Polar basin. Invertebrate Zoology 10 (2): 217-243.

https://doi.org/10.15298/invertzool.10.2.02

Jolly M.T., Jollivet D., Gentil F., Thiébaut E. \& Viard F. 2005. Sharp genetic break between Atlantic and English Channel populations of the polychaete Pectinaria koreni, along the North coast of France. Heredity 94: 23-32. https://doi.org/10.1038/sj.hdy.6800543

Kirkegaard J.B. 1996. Havbørsteorme II. Sedentaria. Danmarks Fauna 86: 1-451.

Kirkegaard J.B. 2001. Polychaetes of the families Glyceridae, Goniadidae and Nereididae from the North Atlantic around Iceland. Sarsia 86: 13-20. https://doi.org/10.1080/00364827.2001.10420457

Linnaeus C. 1767. Systema Naturae. $12^{\text {th }}$ ed. Laurentius Salvius, Stockholm.

Long C.D. 1973. Pectinariidae (Polychaeta) from Caribbean and associated waters. Bulletin of Marine Science 23: 857-874.

Malmgren A.J. 1865. Nordiska Hafs-Annulater. Öfversigt af Konglia Vetenskaps-Akademiens Förlandlingar, Stockholm 21: 51-110, 181-192.

Malmgren A.J. 1866. Nordiska Hafs-Annulater. Öfversigt af Konglia Vetenskaps-Akademiens Förlandlingar, Stockholm 22: 355-410.

Meißner K., Fiorentino D., Schnurr S., Martínez Arbizu P., Huettmann F., Holst S., Brix S. \& Svavarsson J. 2014. Distribution of benthic marine invertebrates at northern latitudes - An evaluation applying multialgorithm species distribution models. Journal of Sea Research 85: 241-254.

https://doi.org/10.1016/j.seares.2013.05.007

Merz R.A. \& Woodin S.A. 2000. Hooked setae: tests of the anchor hypothesis. Invertebrate Biology 119: 67-82. https://doi.org/10.1111/j.1744-7410.2000.tb00175.x

Moreira J. \& Parapar J. 2012. Two new species of Sphaerodoropsis Hartman \& Fauchald, 1971 (Polychaeta: Sphaerodoridae) from Iceland (BIOICE programme). Marine Biology Research 8 (7): 584-593. https://doi.org/10.1080/17451000.2011.638929

Moreira J. \& Parapar J. 2015. A new species of Sphaerodoridium Lützen, 1961 from Iceland (Polychaeta: Sphaerodoridae). Zootaxa 3911 (1): 91-105. https://doi.org/10.11646/zootaxa.3911.1.5

Müller O.F. 1776. Zoologicae Danicae Prodromus, seu Animalium Daniae et Norvegiae indigenarum characteres, nomina et synonyma imprimis popularium. Hallageriis, Havniae, Copenhagen.

https://doi.org/10.5962/bhl.title.13268

Nilsen R., Kirkegaard J.B. \& Lemche H. 1977. Pectinaria Lamarck, 1818 (Polychaeta), and the species names $P$. belgica (Pallas, 1766) and $P$. koreni (Malmgren, 1866) to be validated under the plenary powers. Bulletin of Zoological Nomenclature 34: 112-122. https://doi.org/10.5962/bhl.part.14601

Nilsson D. 1928. Neue und alte Amphicteniden. Göteborgs Kungelige Vetenskaps- och Vitterhets Samhälles Handlingar, Series 4 33: 1-96.

Nishi E., Matsuo K., Kazama-Wakabayashi M., Mori A., Tomioka S., Kajihara S., Hamaguchi M., Kajihara M. \& Hutchings P. 2014. Partial revision of Japanese Pectinariidae (Annelida: Polychaeta), including redescriptions of poorly known species. Zootaxa 3895 (3): 433-445.

https://doi.org/10.11646/zootaxa.3895.3.8 
Nogueira J.M.M., Hutchings P.A. \& Fukuda M.V. 2010. Morphology of terebelliform polychaetes (Annelida: Polychaeta: Terebelliformia), with a focus on Terebellidae. Zootaxa 2460: 1-185. https://doi.org/10.11646/zootaxa.2460.1.1

Nogueira J.M.M., Ribeiro W.M.G., Carrerette O. \& Hutchings P. 2019. Pectinariidae (Annelida, Terebelliformia) from off southeastern Brazil, southwestern Atlantic. Zootaxa 4571 (4): 489-509. https://doi.org/10.11646/zootaxa.4571.4.3

Nygren A., Parapar J., Pons J., Meißner K., Bakken T., Kongsrud J.A., Oug E., Gaeva D., Sikorski A., Johansen R.A., Hutchings P.A., Lavesque N. \& Capa M. 2018. A mega-cryptic species complex hidden among one of the most common annelids in the North East Atlantic. PLoS One 13 (6): e0198356. https://doi.org/10.1371/journal.pone.0198356

Parapar J. 2003. Oweniidae (Annelida, Polychaeta) from Icelandic waters, collected by the BIOICE project, with a description of Myrioglobula islandica n. sp. Sarsia 88: 274-290.

Parapar J. 2006. The genera Myriochele and Myrioglobula (Polychaeta, Oweniidae) in Icelandic waters with the revision of type material of Myriochele heeri Malmgren, 1867, and the description of a new species. Journal of Natural History 40 (9-10): 523-547. https://doi.org/10.1080/00222930600711758

Parapar J., Moreira J. \& Helgason G.V. 2011a. Distribution and diversity of the Opheliidae (Annelida, Polychaeta) on the continental shelf and slope of Iceland, with a review of the genus Ophelina in northeast Atlantic waters and description of two new species. Organisms, Diversity and Evolution 11: 83-105. https://doi.org/10.1007/s13127-011-0046-2

Parapar J., Moreira J. \& Helgason G.V. 2011b. Taxonomy and distribution of Terebellides (Polychaeta, Trichobranchidae) in Icelandic waters, with the description of a new species. Zootaxa 2983: 1-20. https://doi.org/10.11646/zootaxa.2983.1.1

Parapar J., Helgason G.V., Jirkov I. \& Moreira J. 2011c. Taxonomy and distribution of the genus Amphicteis (Polychaeta: Ampharetidae) collected by the BIOICE project in Icelandic waters. Journal of Natural History 45 (23-24): 1477-1499. https://doi.org/10.1080/00222933.2011.558640

Parapar J., Moreira J. \& Helgason G.V. 2013a. First record of genus Orbiniella Day, 1954 (Polychaeta: Orbiniidae) in North Atlantic Ocean with the description of a new species. Zootaxa 4006: 330-346. https://doi.org/10.11646/zootaxa.4006.2.5

Parapar J., Helgason G.V., Jirkov I. \& Moreira J. 2013b. Polychaetes of the genus Ampharete (Polychaeta: Ampharetidae) collected in Icelandic waters during the BIOICE project. Helgoland Marine Research 66: 331-344. https://doi.org/10.1007/s10152-011-0274-z

Parapar J., Aguirrezabalaga F. \& Moreira J. 2014a. First record of Longosomatidae (Annelida: Polychaeta) from Iceland with a worldwide review of diagnostic characters of the family. Journal of Natural History 48 (17-18): 983-998. https://doi.org/10.1080/00222933.2013.859316

Parapar J., Helgason G.V., Jirkov I. \& Moreira J. 2014b. Diversity and taxonomy of Ampharetidae (Polychaeta) from Icelandic waters. Polish Polar Research 35 (2): 311-340.

Petersen M.E. 2000. A new genus of Fauveliopsidae (Annelida: Polychaeta), with a review of its species and redescription of some described taxa. Bulletin of Marine Science 67: 491-515.

Pettibone M.H. 1954. Marine Polychaete worms from Point Barrow, Alaska, with additional records from the North Atlantic and North Pacific. Proceedings of the United States National Museum 103 (3324): 203-356. https://doi.org/10.5479/si.00963801.103-3324.203

Read G. \& Fauchald K. (eds) 2019. World Polychaeta database. Pectinariidae Quatrefages, 1866. Available from http://www.marinespecies.org/aphia.php?p=taxdetails\&id=980 [accessed 17 Mar. 2019]. 
Rouse G.V. \& Pleijel F. 2001. Polychaetes. Oxford University Press, New York.

Sanfilippo R. 2001. Bathyvermilia islandica (Polychaeta, Serpulidae): a new deep-water species from south of Iceland. Sarsia 86: 177-182. https://doi.org/10.1080/00364827.2001.10420473

Sigvaldadóttir E. 2002. Polychaetes of the genera Prionospio and Aurospio (Spionidae, Polychaeta) from Icelandic waters. Sarsia 87: 201-215. https://doi.org/10.1080/00364820260294842

Silva T., Gislason A., Astthorsson O.S. \& Marteinsdóttir G. 2017. Distribution, maturity and population structure of Meganyctiphanes norvegica and Thysanoessa inermis around Iceland in spring. PLoS One 12 (11): e0187360. https://doi.org/10.1371/journal.pone.0187360

Sun Y. \& Qiu J-W. 2012. A new species of Lagis (Polychaeta: Pectinariidae) from Hong Kong. Zootaxa 3264: 61-68. https://doi.org/10.11646/zootaxa.3264.1.4

Wesenberg-Lund E. 1951. Polychaeta. The Zoology of Iceland 2 (19): 1-181.

Wolf P.S. 1984. Family Pectinariidae Quatrefages, 1865. Chapter 50. In: Uebelacker J.M. \& Johnson P.G. (eds) Taxonomic Guide to the Polychaetes of the Northern Gulf of Mexico, Volume VII: 50-1-50-10. U.S. Department of the Interior Minerals Management Service.

Woodin S.A. \& Merz R.A. 1987. Holding on by their hooks: anchors for worms. Evolution 41: 427-432. https://doi.org/10.1111/j.1558-5646.1987.tb05808.x

Zamora J.L., Parapar J., Helgason G.V. \& Moreira J. 2020. Taxonomy and distribution of Icelandic Fauveliopsidae (Annelida) collected during the BIOICE project. Journal of Natural History 53 (47-48): 2951-2954. https://doi.org/10.1080/00222933.2020.1757170

Zhang J. \& Qiu J.W. 2017. A new species of Pectinaria (Annelida, Pectinariidae), with a key to pectinariids from the South China Sea. ZooKeys 683: 139-150. https://doi.org/10.3897/zookeys.683.12272

Zhang J., Zhang Y. \& Qiu J.W. 2015. A new species of Amphictene (Annelida, Pectinariidae) from the northern South China Sea. ZooKeys 545: 27-36. https://doi.org/10.3897/zookeys.545.6454

Zhang J., Hutchings P. \& Kupriyanova E. 2019. A revision of the genus Petta Malmgren, 1866 (Annelida: Pectinariidae), with two new species from deep waters of southeastern Australia, and comments on phylogeny of the family. Zootaxa 4614 (2): 303-330. https://doi.org/10.11646/zootaxa.4614.2.3

Manuscript received: 28 November 2019

Manuscript accepted: 17 March 2020

Published on: 15 June 2020

Topic editor: Rudy Jocqué

Desk editor: Kristiaan Hoedemakers

Printed versions of all papers are also deposited in the libraries of the institutes that are members of the EJT consortium: Muséum national d'histoire naturelle, Paris, France; Meise Botanic Garden, Belgium; Royal Museum for Central Africa, Tervuren, Belgium; Royal Belgian Institute of Natural Sciences, Brussels, Belgium; Natural History Museum of Denmark, Copenhagen, Denmark; Naturalis Biodiversity Center, Leiden, the Netherlands; Museo Nacional de Ciencias Naturales-CSIC, Madrid, Spain; Real Jardín Botánico de Madrid CSIC, Spain; Zoological Research Museum Alexander Koenig, Bonn, Germany; National Museum, Prague, Czech Republic. 